\title{
Bioturbation of Thalassinoides from the Lower Cambrian Zhushadong Formation of Dengfeng area, Henan Province, North China
}

\author{
Yu-Chao Fan, Yong-An Qi, Ming-Yue Dai, Da Li, Bing-Chen Liu and Guo-Shuai Qing
}

\begin{abstract}
Bioturbation plays a critical role in sediment mixing and biogeochemical cycling between sediment and seawater. An abundance of bioturbation structures, dominated by Thalassinoides, occurs in carbonate rocks of the Cambrian Series 2 Zhushadong Formation in the Dengfeng area of western Henan Province, North China. Determination of elemental geochemistry can help to establish the influence of burrowing activities on sediment biogeochemical cycling, especially on changes in oxygen concentration and nutrient regeneration. Results show that there is a dramatic difference in the bioturbation intensity between the bioturbated limestone and laminated dolostone of the Zhushadong Formation in terms of productivity proxies ( $\mathrm{Ba}_{\mathrm{ex}}, \mathrm{Cu}, \mathrm{Ni}, \mathrm{Sr} / \mathrm{Ca}$ ) and redox proxies $(\mathrm{V} / \mathrm{Cr}, \mathrm{V} / \mathrm{Sc}, \mathrm{Ni} /$ Co). These changes may be related to the presence of Thalassinoides bioturbators, which alter the particle size and permeability of sediments, while also increase the oxygen concentration and capacity for nutrient regeneration. Comparison with modern studies shows that the sediment mixing and reworking induced by Thalassinoides bioturbators significantly changed the primary physical and chemical characteristics of the Cambrian sediment, triggering the substrate revolution and promoting biogeochemical cycling between sediment and seawater.
\end{abstract}

Keywords: Thalassinoides, Sediment mixing, Oxygen concentration, Nutrient regeneration, Trace element proxy, Early Cambrian, North China Platform

\section{Introduction}

Bioturbation is a biological process that results in the disruption of primary physical sedimentary structures, in particular, stratification (Qi 1999; Seilacher 1999). The sediment mixing by burrowing animals can significantly alter the physicochemical properties of sediments and biogeochemical cycling between sediment and seawater (Canfield and Farquhar 2009; Boyle et al. 2014, 2018; Tarhan 2018). Mixing of Cambrian sediments by bioturbation substrate evolution is one of the most profound environmental changes caused by organisms in life history. Burrowing animals explored microbial mat

\footnotetext{
* Correspondence: qiya@hpu.edu.cn

School of Resources and Environment, Henan Polytechnic University, Jiaozuo 454000, Henan Province, China
}

\section{Springer Open}

substrate for the first time during the Ediacaran (Dornbos et al. 2005; Chen et al. 2013; Buatois et al. 2014), but only penetrated the uppermost few centimeters of the sediment and caused little disturbance to the primary sedimentary fabric. Trace fossils in the Fortunian, earliest Cambrian, indicate that these organisms exhibited complex and widely variable behavioral patterns. The well-developed suspension-feeding infaunal communities colonized the deep infaunal ecospace in mobile sandy substrates of high- to moderate-energy coastal settings, indicating that they were able to expand their spatial range within the ecosystem for the Cambrian Series 2 (Mángano and Buatois 2004, 2014). Capture of organic particles by suspension feeders allowed enrichment of organic matter by biodeposition, promoting diversification of deposit-

(c) The Author(s). 2021 Open Access This article is licensed under a Creative Commons Attribution 4.0 International License, which permits use, sharing, adaptation, distribution and reproduction in any medium or format, as long as you give appropriate credit to the original author(s) and the source, provide a link to the Creative Commons licence, and indicate if changes were made. The images or other third party material in this article are included in the article's Creative Commons licence, unless indicated otherwise in a credit line to the material. If material is not included in the article's Creative Commons licence and your intended use is not permitted by statutory regulation or exceeds the permitted use, you will need to obtain permission directly from the copyright holder. To view a copy of this licence, visit http://creativecommons.org/licenses/by/4.0/. 
feeding strategies during Cambrian Epoch 3 (Mángano and Buatois 2014). The occurrence of high-density and deep-tier Thalassinoides mazes penetrating several storm layers in the Cambrian Stage 4 of China is evidence that the increasing sediment reworking ability of bioturbators not only significantly modified the primary sedimentary fabric, but also efficiently created new ecological space (Qi et al. 2014; Zhang et al. 2017).

The activities of deep-tier bioturbators, e.g. Thalassinoides, can not only transport solutes within burrows to the surface (Zhang et al. 2017), but also increase the water content in sediments by extending the sedimentwater interface area, and resulting in physical redistribution of nutrients (Aller 1994; Michaud et al. 2005, 2006). Burrowing animals foraging in the sediment increase sediment permeability (Lohrer et al. 2004) and improve sediment carbon cycling (Boyle et al. 2014, 2018), while also improve oxygen levels and increase sulfur cycling in the sediment (Canfield and Farquhar 2009). The bioturbation of sediments by benthic macrofauna imposes major changes on important sediment biogeochemical processes, such as fluid exchange between the water column and sediment, sediment redox properties and nutrient cycling (Mángano and Buatois 2014; Zhang et al. 2017). Bioturbation activities influence sediment stability, grain size and grain distribution, and also modify the benthic microenvironment and the utilization of resources, consequently changing the suitable living space and colonizing conditions (Mángano and Buatois 2014). Therefore, burrowing animals significantly modify the primary sedimentary fabric, efficiently contribute to nutrient cycling and serve as ecosystem engineers (Mángano and Buatois 2014).

Current ichnologic and sedimentologic evidence from North China shows that intense bioturbation, dominated by ichnogenus Thalassinoides, is well preserved in nearshore carbonate rocks formed during the Early Cambrian period, providing evidence of significant sediment mixing. The comparison of burrows with modern architectures allows evaluation of the role of these deep bioturbators in sediment mixing, geochemical cycling and ecosystem engineering. This paper concentrates on bioturbation by Thalassinoides, which is commonly found in shallow marine carbonates of the Lower Cambrian Zhushadong Formation in North China, with the aim to establish how burrows influenced the sediment and carbonate ecosystem.

\section{Geological environments}

The North China Platform was formed during the Cambrian period and located near the palaeo-equator, comprising a stable epeiric sea surrounded by abyssal troughs of the northern Palaeo-Asian Ocean, the southern Palaeo-Qinling Ocean, and the western Palaeo-
Qilian Ocean (Yang et al. 2002). Deposition of the platform began during the Cambrian Epoch 2, in the aftermath of widespread transgression (Zhang et al. 2015). Cambrian Series 2 strata (see Figs. 1c, 2) consist of epeiric siliciclastic sediments and muddy limestones (Xinji Formation), carbonates (Zhushadong Formation), and intertidal to supratidal mudstones and siltstones (Mantou Formation, Member I). The Cambrian Miaolingian started with intertidal mixed siliciclastic-carbonate sediments of the Mantou Formation, Members II-III, evolving to form micritic limestone, microbialite and oolitic limestone on the carbonate platform during the deposition of Zhangxia Formation and Gushan Formation. The Chaomidian Formation and Sanshanzi Formation of the Cambrian Furongian are dominated by intertidal to subtidal dolostone interbedded with micritic limestone (Pei et al. 2008).

The Guankou section is located northeast of Dengfeng City, Henan Province, in the southern part of the North China Platform (Fig. 1). The Zhushadong Formation overlies muddy limestones of the Xinji Formation and underlies mudstones of the Mantou Formation (Fig. 2). The Zhushadong Formation is well exposed in the Dengfeng area and can be subdivided into three lithostratigraphic units (Member I-Member III) in an ascending order (Figs. 2, 3a). Member I is $6.9 \mathrm{~m}$ thick consisting of gray laminated dolostone which essentially exhibits no biogenic disturbance and preserves the primary fabric of the sediment (Figs. 2, 3b). Stromatolites, horizontal bedding, parallel lamination and convolute lamination are common in Member I, and chert is also present locally (Figs. 2, 3c). These characteristics suggest that Member I was formed in an onshore tidal flat environment. Member II is $\mathbf{1 3 . 7 5}$ $\mathrm{m}$ thick in the Guankou section and is composed dominantly of gray/black bioturbated limestone, referred to as leopard limestone. The bioturbation is characteristic of a monospecific Thalassinoides, with burrow fillings being gray/black in color, surrounded by a light gray matrix and clear boundaries on the bedding surface (Figs. 2, 3d). Moreover, up-section Thalassinoides evolved from primarily horizontal network to boxwork systems. This phenomenon reveals a decrease in water energy. In addition, the burrow systems also became more complex up-section and the bioturbation index increased, suggesting that Member II formed in a shallow subtidal ramp environment. Member III extends $4 \mathrm{~m}$ and consists of gray-dark gray laminated dolostone. It exhibits similar characteristics to Member I, suggesting that Member III formed in an onshore tidal flat environment (Figs. 2, 3e).

\section{Methods}

The bioturbation index (BI) represents the clarity of primary sedimentary fabric and was used to assess the degree of bioturbation. The classification scheme proposed 


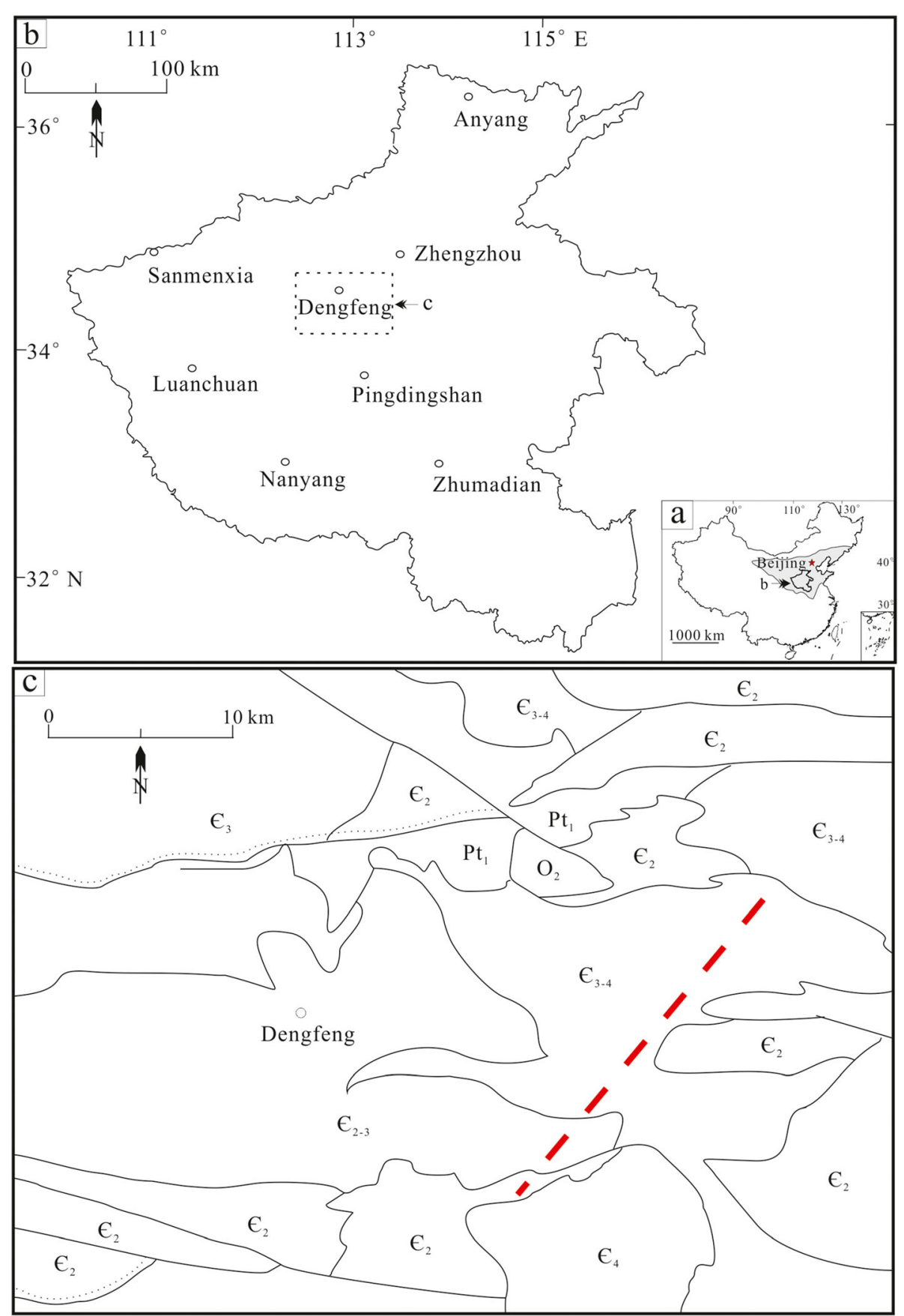

Fig. 1 Maps indicating the location and geology of the study area. a Geographic location of Henan Province in North China (the inset map of China is referring the standard map available on the official website of Ministry of Natural Resources of China: http://bzdt.ch.mnr.gov.cn/). Note that the gray shadow stands for the boundary of the North China Platform; $\mathbf{b}$ Geographic location of the studied Dengfeng area in Henan Province; c Geological map of the Dengfeng area. Note that the bold red dashed line shows the Guankou section

by Taylor and Goldring (1993) refers to the percentage of disturbed sediment in a sediment unit, due to biological activities. This scheme utilizes seven grades, ranging from 0 (no bioturbation) to 6 (complete disturbance of the sediment) (Table 1).
All 22 samples for major and trace element analyses were collected at approximately $0.5-2 \mathrm{~m}$ intervals and collected from fresh, relatively unweathered, fine-grained carbonate rocks in the Guankou section, with sample weight varying between $10 \mathrm{~g}$ and $30 \mathrm{~g}$. Carbonate 


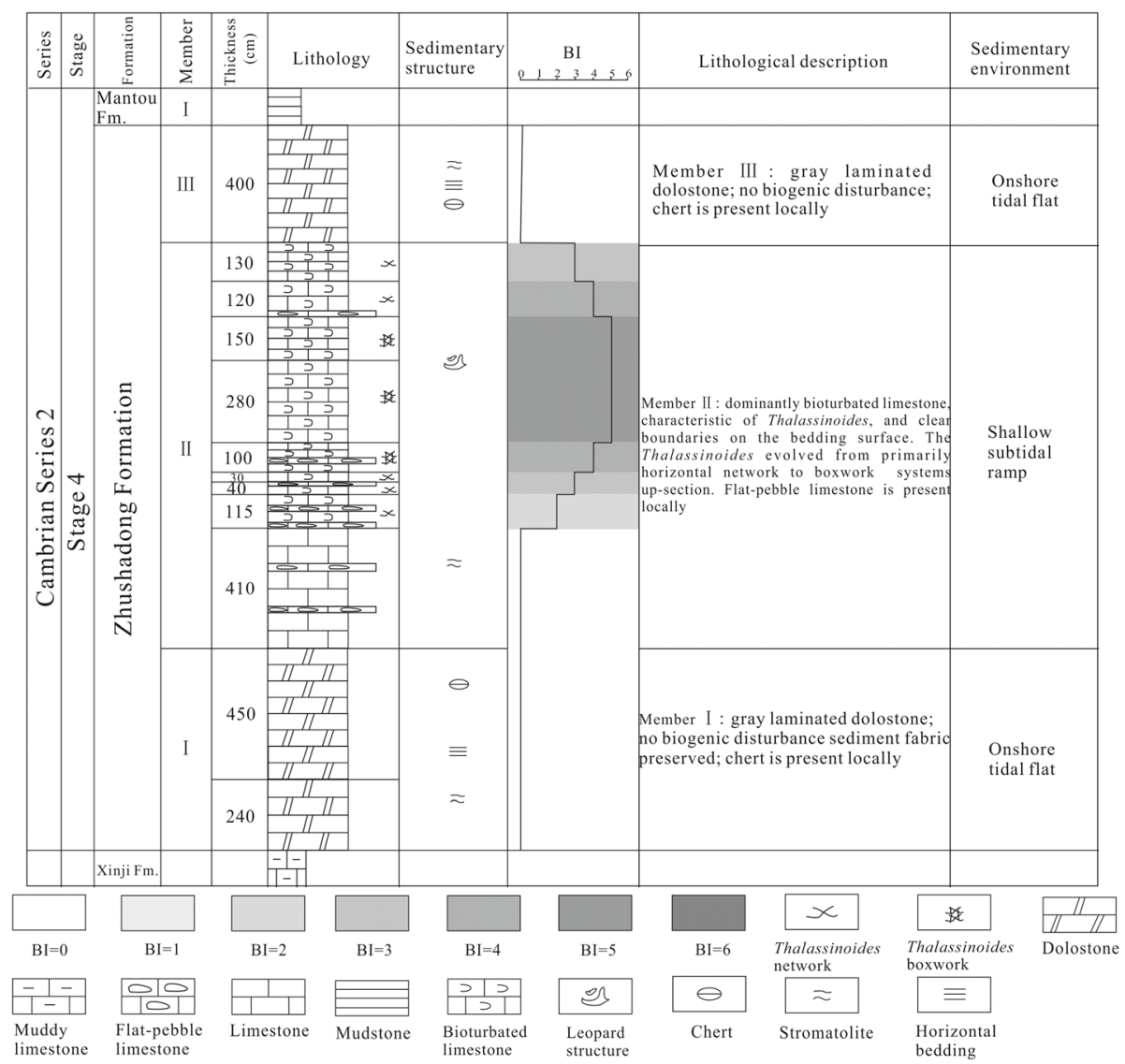

Fig. 2 Lithostratigraphic column and sedimentological features of the Lower Cambrian Zhushadong Formation in the Guankou section. BI= Bioturbation index (0-6)

concretions, thin irregular beds and lenses within shaledominated sediments were avoided during sampling. The sampling range started from the top of the Xinji Formation, and ended in the bottom of the Mantou Formation, ensuring that the deposition of the Zhushadong Formation was completely spanned. Major and trace element analyses were carried out using an Agilent 7700e ICP-MS, by the ALS Laboratory Group, Mineral Division (Guangzhou). Analytical precision for trace element concentrations was greater than $95 \%$ and detection limits were less than or equal to $2 \mathrm{ppm}$ in most cases, while the detection limits for $\mathrm{Ba}, \mathrm{Cr}, \mathrm{Rb}, \mathrm{Sr}$, and $\mathrm{V}$ were $5 \mathrm{ppm}$.

\section{Results}

\subsection{Thalassinoides analysis}

In the study area, the lower Zhushadong Formation (Member I; Figs. 2, 3) essentially exhibits no biogenic disturbance and preserves the primary sediment fabric, being characterized by algal and parallel lamination (Qi et al. 2014; Zhang et al. 2017). However, intense bioturbation characterized by Thalassinoides occurs in the middle Zhushadong Formation (Member II; Figs. 2, 3). All
Thalassinoides are preserved in full relief in limestone of the middle Zhushadong Formation, where the boundaries between the burrows and the host rock are clearly visible. The bioturbation structures are black and/or dark-gray and protrude above the bedding planes, while the host rock is gray/light-gray (Fig. 4). Thalassinoides typically forms boxwork systems and networks and has visible short vertical shafts on bedding surfaces, with specimens being smooth, lacking wall reinforcements and mainly consisting of horizontal-branched burrows (Fig. 4). The diameter of Thalassinoides varies little, commonly being in the range of $3-10 \mathrm{~mm}$, with some reaching $15 \mathrm{~mm}$. The diameter of branches is slightly smaller than the main branch, while the penetration of individual burrow shafts can reach an average of $37 \mathrm{~mm}$. This is similar to the excavation depth of burrowing organisms in other Cambrian strata (Tarhan 2018), except for the Guankou section, where the maximum bioturbated zone is amalgamated to form a thickness of up to $170 \mathrm{~cm}$, suggesting that the influence of bioturbation on sediment oxygen and nutrient levels in this section is great (Zhang et al. 2017). 

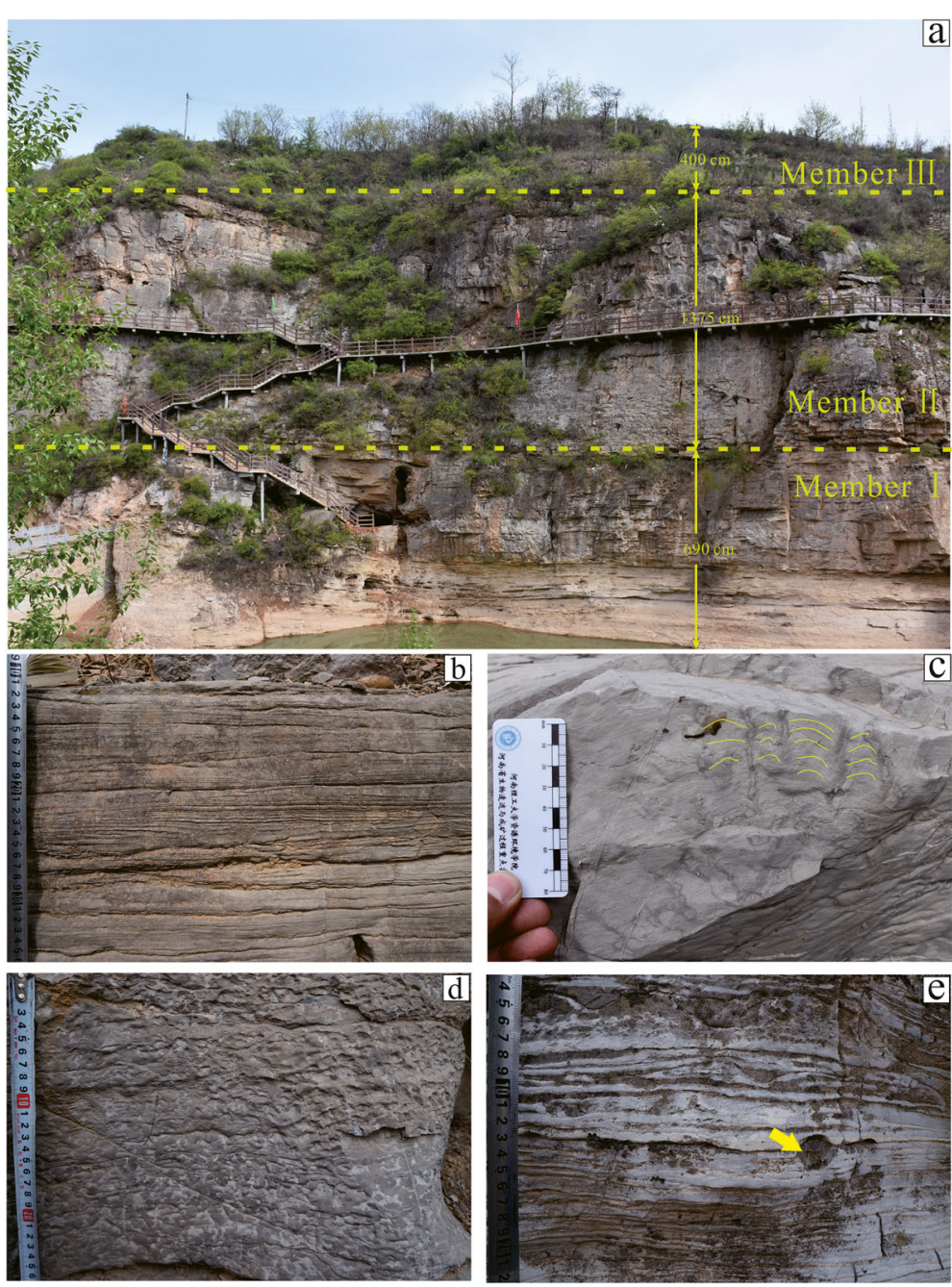

Fig. 3 Outcrop photographs of the Zhushadong Formation. a Overview of the Zhushadong Formation succession in the Guankou section in Dengfeng area; the yellow dashed lines show the contacts between laminated dolostones (Member I and Member III respectively) and bioturbated limestone (Member II); $\mathbf{b}$ The lower laminated dolostone (Member I) preserves primary fabric, characteristic of algal and parallel lamination; c Stromatolites developed locally in the lower laminated dolostone (Member I); d Burrow filling of Thalassinoides in Member II is gray to black; matrix is light gray; e Chert (indicated by the arrow) is developed locally in the upper laminated dolostone (Member III)

Table 1 Classification scheme of the bioturbation index (BI) (modified from Taylor and Goldring 1993)

\begin{tabular}{lll}
\hline BI & Percentage of the disturbed sediment (\%) & Description \\
\hline 0 & 0 & No bioturbation \\
1 & $1-5$ & Sparse bioturbation, few biogenic structures visible \\
2 & $6-30$ & Low bioturbation, well-preserved sedimentary fabric \\
3 & $31-60$ & Moderate bioturbation, well-preserved sedimentary fabric \\
4 & $61-90$ & Intense bioturbation, high trace fossil density, with overlap of trace fossils \\
5 & $91-99$ & Intense bioturbation, completely disturbed sediment \\
6 & 100 & Complete bioturbation, with sediment fully reworked \\
\hline
\end{tabular}



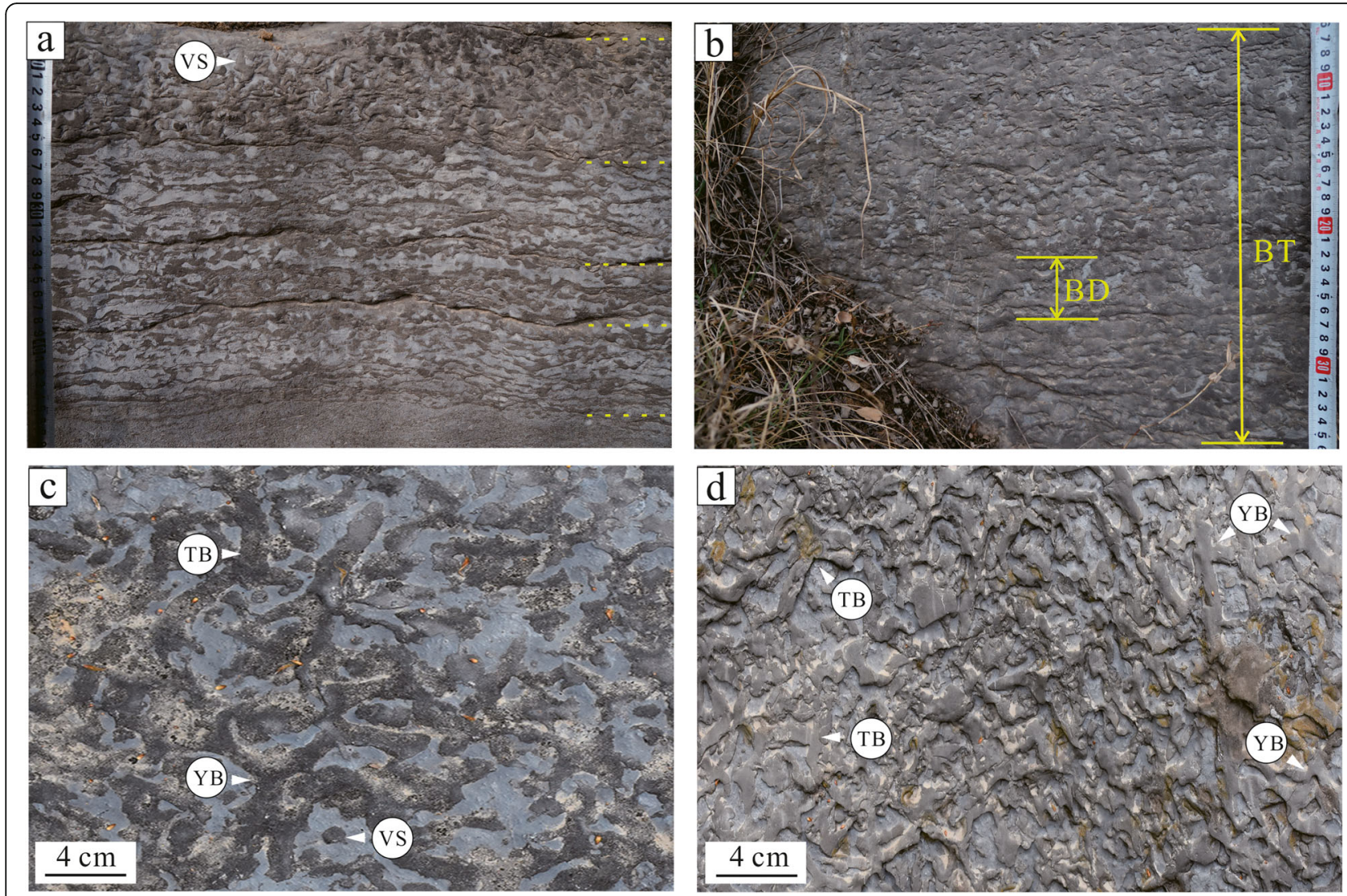

Fig. 4 Different grades of Thalassinoides bioturbation in the Zhushadong Formation of the Guankou section. a Thalassinoides representing multilayer colonizers, cross-section view. In the more intensely bioturbated beds, bedding-parallel networks are linked by vertical shafts; $\mathbf{b}$ Intense bioturbation in cross section. Penetration of individual burrow shafts is up to $3.7 \mathrm{~cm}$, the bioturbated zone is amalgamated forming up to a $30-$ cm-thick layer; c Thalassinoides representing mainly horizontally branching burrows. Most burrows form both Y-and T-shaped branchings. Locally, vertical shafts are seen on bedding surfaces; $\mathbf{d}$ Thalassinoides boxwork. Most burrows exhibit both $Y$ - and T-shaped branchings, which can be observed both on bedding surfaces and in the cross section. Abbreviations: VS=Vertical shaft; $B D=$ Burrow depth, maximum burrow depth during multi-layer colonization; BT = Thickness of bioturbated zone; YB = Y-shaped branching; TB = T-shaped branching

Application of Image J2x Analysis Software in measuring the spacing between Thalassinoides burrows was conducted with bed-by-bed measurements of the percentage of Thalassinoides bioturbation. Results show that the Thalassinoides burrow interspace is commonly within $5 \mathrm{~mm}$. The percentage of disturbed sediment was assessed and the bioturbation index (BI) was found to be in the range of 2-5. The BI value of 2 indicates a low level of bioturbation, with burrow diameters within 3-4 $\mathrm{mm}$; this bioturbation degree $(\mathrm{BI}=2)$ means that bioturbation structures would exhibit in the form of continuous bands parallel to bedding, with $10 \%-20 \%$ percentage of the disturbed sediment. The BI value of 3 refers to moderate bioturbation in which the case burrow diameter is $4-6 \mathrm{~mm}$, with bioturbation structures in the form of continuous strips parallel to bedding, and bioturbated beds linked by occasional vertical shafts (Fig. 4). In these cases, most of the burrows are single tunnels, with a few Y-shaped branchings on the bedding surfaces (Fig. 4). These structures contain no swellings at junctions and little overlap with each other. The corresponding percentage of the disturbed sediment accounts for $31 \%-55 \%$. The BI value of 4 is characterized by intense bioturbation with burrow diameters of 5-12 mm. Bioturbation structures form indeterminate directional $\mathrm{Y}$ - or T-shaped branchings on bedding surfaces, with branchings being slightly swollen (Fig. 4). The disturbance depth is deeper and burrows commonly overlap, with vertical networks existing locally (Fig. 4), and, the disturbed sediment accounts for $61 \%-84 \%$ of the whole sediment unit area. The BI value of 5 stands for intense bioturbation characterized by completely disturbed sediments with burrow diameters of $8-13 \mathrm{~mm}$. Most burrows exhibit both Y- and T-shaped branchings, which can be observed both on bedding surfaces and in the cross section (Fig. 4), and completely overlapping burrows are also visible. The intensive bioturbation level modifies the depositional interface completely, with the percentage of the disturbed sediment accounting for more than $90 \%$. 
To further analyze the bioturbation structure and composition as well as the host-rock structural characteristics, thin-sections were observed by optical microscopy after alizarin red staining (Fig. 5). The microscopic features show that the boundary between the filling and host rock is very sharp. The filling of burrows consists of euhedral and semieuhedral crystalline dolomite, whereas the host rock is dominated by micrite calcite containing a small amount of semi-euhedral dolomite crystals scattered throughout. In addition, the particle diameter in the host rock is clearly smaller than that of the filling (Fig. 5). The euhedral and semi-euhedral dolomite crystals in the burrow filling were produced by diagenetic dolomite replacement which preferentially began within the burrow systems.

\subsection{Geochemical characteristics}

\subsubsection{Major element characteristics}

All the samples from the Zhushadong Formation in the Guankou section were used for major element analysis (data in Table 2). The $\mathrm{CaO}$ and $\mathrm{MgO}$ concentrations of the samples were relatively high, with average value of $39.95 \%$ and $12.74 \%$, respectively. The concentrations of typical detrital-origin oxides, $\mathrm{SiO}_{2}, \mathrm{Al}_{2} \mathrm{O}_{3}, \mathrm{~K}_{2} \mathrm{O}$, and $\mathrm{Ti}_{2} \mathrm{O}$, were relatively low with average values of $2.23 \%$, $0.27 \%, 0.13 \%$, and $0.01 \%$, respectively. Thus, the major element characteristics confirm that terrestrial detritus was minimally involved in the deposition of the Zhushadong Formation in the Guankou section, which is a fully marine deposit.

\subsubsection{Trace element characteristics}

Trace element data of the samples from the Zhushadong Formation are given in Table 3. The distribution of trace elements in samples of the study area is consistent with that of the average upper continent crust (AUCC; McLennan 2001) (Fig. 6), indicating that the Zhushadong Formation was formed in a relatively stable sedimentary environment. The concentration of Sr (average
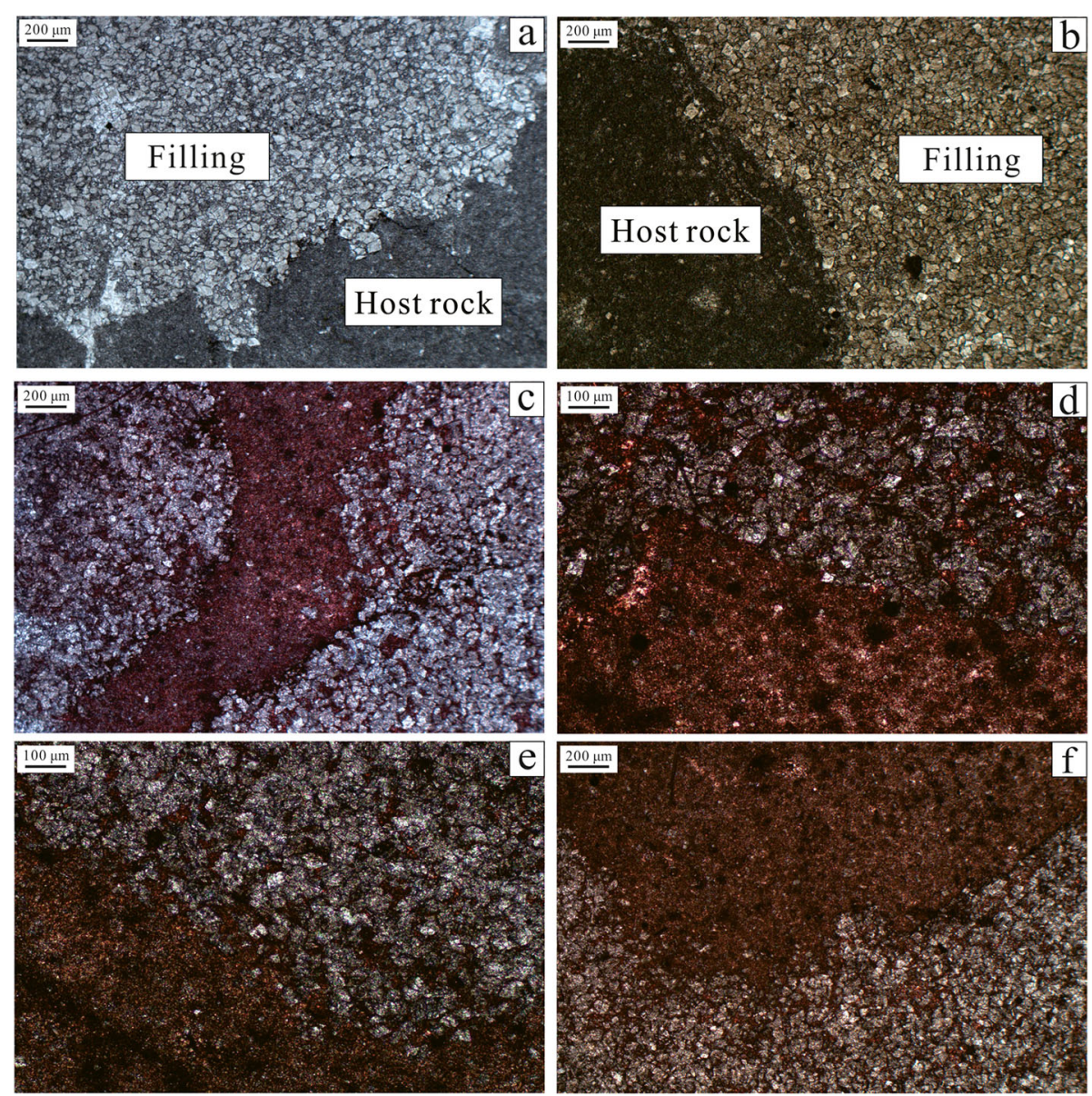

Fig. 5 Microfabrics of Thalassinoides in the Zhushadong Formation of the Guankou section. $\mathbf{a}-\mathbf{b}$ The boundary between filling and host rock is sharp, the filling consists of euhedral and semi-euhedral crystalline dolomites, whereas the host rock is dominated by microcrystalline calcite; c-f After alizarin red staining, the white part of burrow filling consists of semi-euhedral dolomites, and the red part of host rock is dominated by microcrystalline calcites. The boundary between filling and host rock is sharp, and, particles in the host rock are clearly smaller than those in the filling 
Table 2 Major element data (\%) listed with rock types for the Zhushadong Formation samples

\begin{tabular}{|c|c|c|c|c|c|c|c|c|c|c|c|c|c|c|}
\hline Samples & Lithology & $\mathrm{SiO}_{2}$ & $\mathrm{Al}_{2} \mathrm{O}_{3}$ & $\mathrm{CaO}$ & $\mathrm{TFe}_{2} \mathrm{O}_{3}$ & $\mathrm{~K}_{2} \mathrm{O}$ & $\mathrm{MgO}$ & $\mathrm{MnO}$ & $\mathrm{TiO}_{2}$ & $\mathrm{Na}_{2} \mathrm{O}$ & $\mathrm{P}_{2} \mathrm{O}_{5}$ & $\mathrm{SO}_{3}$ & SrO & LOI \\
\hline $\mathrm{Z}-1$ & Dolostone & 2.58 & 0.16 & 30.20 & 0.36 & 0.07 & 20.70 & 0.03 & $<0.01$ & $<0.01$ & $<0.01$ & $<0.01$ & $<0.01$ & 45.10 \\
\hline$Z-2$ & Dolostone & 3.40 & 0.12 & 30.20 & 0.34 & 0.06 & 20.80 & 0.03 & $<0.01$ & $<0.01$ & $<0.01$ & 0.01 & $<0.01$ & 44.17 \\
\hline Z-3 & Dolostone & 2.80 & 0.33 & 29.90 & 0.36 & 0.18 & 20.70 & 0.03 & 0.01 & 0.03 & $<0.01$ & 0.06 & $<0.01$ & 45.54 \\
\hline$Z-4$ & Dolostone & 4.94 & 0.82 & 29.30 & 0.56 & 0.47 & 19.70 & 0.03 & 0.04 & 0.04 & 0.01 & 0.08 & 0.01 & 44.22 \\
\hline$Z-5$ & Dolostone & 3.61 & 0.25 & 29.80 & 0.34 & 0.17 & 20.40 & 0.02 & $<0.01$ & $<0.01$ & $<0.01$ & 0.06 & $<0.01$ & 45.30 \\
\hline$Z-6$ & Limestone & 1.05 & 0.05 & 53.20 & 0.05 & 0.04 & 2.50 & 0.01 & $<0.01$ & $<0.01$ & $<0.01$ & 0.04 & 0.02 & 43.19 \\
\hline$Z-7$ & Limestone & 1.08 & 0.10 & 53.90 & 0.11 & 0.07 & 1.64 & 0.01 & $<0.01$ & $<0.01$ & $<0.01$ & 0.05 & 0.02 & 43.30 \\
\hline Z-8 & Limestone & 1.00 & 0.03 & 53.20 & 0.08 & 0.04 & 2.43 & 0.01 & $<0.01$ & $<0.01$ & $<0.01$ & 0.05 & 0.02 & 43.38 \\
\hline Z-9 & Bioturbated limestone & 0.94 & 0.08 & 52.40 & 0.09 & 0.06 & 3.06 & 0.01 & $<0.01$ & $<0.01$ & $<0.01$ & 0.04 & 0.02 & 43.73 \\
\hline $\mathrm{Z}-10$ & Bioturbated limestone & 0.80 & 0.08 & 54.10 & 0.12 & 0.07 & 1.94 & 0.01 & $<0.01$ & $<0.01$ & $<0.01$ & 0.04 & 0.02 & 43.58 \\
\hline$Z-11$ & Bioturbated limestone & 2.01 & 0.35 & 37.20 & 0.26 & 0.24 & 14.95 & 0.02 & 0.01 & $<0.01$ & $<0.01$ & 0.04 & 0.01 & 44.17 \\
\hline $\mathrm{Z}-12$ & Bioturbated limestone & 2.05 & 0.31 & 37.40 & 0.23 & 0.23 & 14.70 & 0.02 & 0.01 & $<0.01$ & $<0.01$ & 0.05 & 0.01 & 44.01 \\
\hline$Z-13$ & Bioturbated limestone & 1.43 & 0.25 & 39.40 & 0.20 & 0.21 & 13.45 & 0.02 & 0.01 & $<0.01$ & $<0.01$ & 0.04 & 0.01 & 44.21 \\
\hline$Z-14$ & Bioturbated limestone & 1.41 & 0.26 & 38.90 & 0.24 & 0.20 & 14.00 & 0.02 & 0.01 & $<0.01$ & $<0.01$ & 0.04 & 0.02 & 44.50 \\
\hline$Z-15$ & Bioturbated limestone & 1.34 & 0.25 & 41.00 & 0.21 & 0.20 & 12.25 & 0.02 & 0.01 & $<0.01$ & $<0.01$ & 0.04 & 0.02 & 43.82 \\
\hline $\mathrm{Z}-16$ & Bioturbated limestone & 1.46 & 0.32 & 38.90 & 0.23 & 0.13 & 13.60 & 0.02 & 0.02 & $<0.01$ & $<0.01$ & 0.04 & 0.01 & 44.46 \\
\hline$Z-17$ & Bioturbated limestone & 1.52 & 0.34 & 38.90 & 0.23 & 0.12 & 13.80 & 0.02 & 0.01 & $<0.01$ & $<0.01$ & 0.03 & 0.01 & 44.28 \\
\hline $\mathrm{Z}-18$ & Bioturbated limestone & 1.56 & 0.33 & 39.20 & 0.25 & 0.12 & 13.85 & 0.02 & 0.02 & $<0.01$ & $<0.01$ & 0.03 & 0.01 & 44.46 \\
\hline Z-19 & Bioturbated limestone & 2.50 & 0.38 & 46.00 & 0.20 & 0.09 & 7.42 & 0.01 & 0.01 & $<0.01$ & $<0.01$ & 0.05 & 0.01 & 43.47 \\
\hline$Z-20$ & Bioturbated limestone & 2.58 & 0.41 & 45.30 & 0.23 & 0.09 & 8.18 & 0.01 & 0.02 & $<0.01$ & $<0.01$ & 0.06 & 0.02 & 43.58 \\
\hline$Z-21$ & Dolostone & 4.54 & 0.30 & 30.20 & 0.21 & 0.03 & 20.10 & 0.02 & 0.01 & 0.03 & $<0.01$ & 0.05 & 0.01 & 43.54 \\
\hline $\mathrm{Z}-22$ & Dolostone & 4.52 & 0.32 & 30.30 & 0.21 & 0.03 & 20.00 & 0.02 & 0.01 & 0.02 & $<0.01$ & 0.05 & $<0.01$ & 43.63 \\
\hline Average & - & 2.23 & 0.27 & 39.95 & 0.23 & 0.13 & 12.74 & 0.02 & 0.01 & 0.01 & 0.01 & 0.05 & 0.01 & 44.07 \\
\hline
\end{tabular}

"<0.01" signifies below the detection line

of $116.59 \mathrm{ppm})$ is distinctly higher compared with the average upper continent crust element content (McLennan 2001), while U (average $0.41 \mathrm{ppm}$ ) and $\mathrm{Zn}$ (average $8.95 \mathrm{ppm})$ are slightly enriched compared with the average upper continent crust element content (McLennan 2001). The average concentration of all other trace elements are generally lower than their corresponding average upper continent crust element content (McLennan 2001), and $\mathrm{Cr}, \mathrm{Ni}, \mathrm{Rb}, \mathrm{Ba}$ show more distinct losses (Fig. 6). Although the geochemical properties of $\mathrm{Sr}$ and $\mathrm{Ba}$ are very similar, these two trace elements contain different ionic radii. Therefore, $\mathrm{Ba}^{2+}$ can replace $\mathrm{K}^{+}$, whereas $\mathrm{Sr}^{2+}$ can replace both $\mathrm{Ca}^{2+}$ and $\mathrm{K}^{+}$, leading to a more limited distribution of $\mathrm{Ba}^{2+}$ (Liu et al. 1984). Furthermore, $\mathrm{Sr}$ is enriched in seawater, with higher concentration than $\mathrm{Ca}$, while $\mathrm{Ba}$ has a relatively low concentration in seawater and can be easily adsorbed by clay. Therefore, $\mathrm{Sr}$ enrichment and $\mathrm{Ba}$ loss occur in the marine carbonates and evaporites with low clay concentrations and high $\mathrm{Mg}^{2+}$ and $\mathrm{Ca}^{2+}$ loadings, relative to the average upper continent element content, reflecting the high salinization characteristics of marine pore waters.
Furthermore, the negative anomalies of the trace elements $\mathrm{Ni}$ and $\mathrm{V}$ also indicate that the samples of the Zhushadong Formation have good adsorption efficiency. Hence, the study area was shielded from terrigenous debris, serving as a marine diagenetic fluid deposit with low argillaceous concentrations during the sedimentation period.

\section{Discussion}

Throughout different geological periods of marine environments, Thalassinoides is considered to be one of the most complex burrow systems (Zhang et al. 2017). The trace fossil is relatively common in marine deposits and is usually interpreted as feeding and/or dwelling burrow, with characteristic two-dimensional and threedimensional structures (Nickell and Atkinson 1995; Carvalho et al. 2007). Thalassinoides bioturbation was observed in shallow-marine carbonates of the Lower Cambrian Zhushadong Formation in the Guankou section, providing important evidence of the effect of bioturbation in sediments. 
Table 3 Trace element data (ppm) listed with rock types for the Zhushadong Formation samples. Standard data of the average upper continent crust (AUCC) are from McLennan (2001)

\begin{tabular}{|c|c|c|c|c|c|c|c|c|c|c|c|c|c|c|c|c|c|c|c|c|}
\hline Sample & Lithology & $\mathrm{Ba}$ & Co & $\mathrm{Cr}$ & $\mathrm{Cu}$ & $\mathrm{Ni}$ & $\mathrm{Rb}$ & Sc & $\mathrm{Sr}$ & Th & U & v & $Y$ & $\mathrm{Zn}$ & $\mathrm{Ca}$ & $\mathrm{Ba}_{\mathrm{ex}}$ & $\begin{array}{l}\mathrm{V} / \\
\mathrm{Cr}\end{array}$ & $\begin{array}{l}\mathrm{Ni} / \\
\mathrm{Co}\end{array}$ & $\mathrm{V} / \mathrm{Sc}$ & $\begin{array}{l}\mathrm{Sr} / \\
\mathrm{Ca}\end{array}$ \\
\hline$\overline{Z-1}$ & Dolostone & 11.10 & 0.90 & 2.00 & 2.40 & 0.80 & 2.40 & 0.70 & 50.60 & 0.29 & 0.33 & 15.00 & 1.00 & 31.00 & 70.97 & 11.09 & 7.50 & 0.89 & 21.40 & 0.71 \\
\hline$Z-2$ & Dolostone & 8.70 & 0.70 & 2.00 & 2.10 & 1.00 & 1.70 & 0.50 & 46.70 & 0.16 & 0.21 & 9.00 & 0.80 & 19.00 & 70.97 & 8.69 & 4.50 & 1.43 & 18.00 & 0.66 \\
\hline Z-3 & Dolostone & 14.10 & 0.90 & 3.00 & 2.60 & 1.40 & 4.00 & 0.90 & 63.70 & 0.44 & 0.37 & 11.00 & 0.90 & 4.00 & 70.27 & 14.09 & 3.67 & 1.56 & 12.20 & 0.91 \\
\hline$Z-4$ & Dolostone & 22.40 & 1.60 & 3.00 & 2.50 & 2.30 & 10.40 & 1.40 & 63.30 & 1.19 & 0.43 & 10.00 & 3.60 & 3.00 & 68.86 & 22.38 & 3.33 & 1.44 & 7.10 & 0.92 \\
\hline Z-5 & Dolostone & 13.90 & 0.70 & 2.00 & 1.90 & 1.00 & 3.10 & 0.70 & 64.00 & 0.30 & 0.27 & 7.00 & 0.70 & 2.00 & 70.03 & 13.89 & 3.50 & 1.43 & 10.00 & 0.91 \\
\hline$Z-6$ & Limestone & 4.50 & 0.90 & 2.00 & 1.50 & 0.30 & 0.90 & 0.60 & 135.50 & 0.12 & 0.20 & 4.00 & 0.50 & 9.00 & 125.02 & 4.49 & 2.00 & 0.33 & 6.70 & 1.08 \\
\hline Z-7 & Limestone & 4.60 & 1.00 & 3.00 & 1.70 & 0.70 & 1.40 & 1.00 & 166.50 & 0.19 & 0.35 & 4.00 & 0.60 & 26.00 & 126.67 & 4.59 & 1.33 & 0.70 & 4.00 & 1.31 \\
\hline$Z-8$ & Limestone & 4.20 & 1.00 & 2.00 & 1.70 & 0.60 & 0.80 & 0.60 & 141.00 & 0.12 & 0.23 & 4.00 & 0.40 & 4.00 & 125.02 & 4.19 & 2.00 & 0.60 & 6.70 & 1.13 \\
\hline Z-9 & $\begin{array}{l}\text { Bioturbated } \\
\text { limestone }\end{array}$ & 4.20 & 1.00 & 3.00 & 1.70 & 0.60 & 1.10 & 0.60 & 157.50 & 0.14 & 0.33 & 3.00 & 0.50 & 3.00 & 123.14 & 4.19 & 1.00 & 0.60 & 5.00 & 1.28 \\
\hline$Z-10$ & $\begin{array}{l}\text { Bioturbated } \\
\text { limestone }\end{array}$ & 4.50 & 1.30 & 2.00 & 1.70 & 0.60 & 1.40 & 0.60 & 175.00 & 0.14 & 0.44 & 3.00 & 0.50 & $\begin{array}{l}< \\
2.00\end{array}$ & 127.14 & 4.49 & 1.50 & 0.46 & 5.00 & 1.38 \\
\hline Z-11 & $\begin{array}{l}\text { Bioturbated } \\
\text { limestone }\end{array}$ & 12.80 & 1.10 & 3.00 & 2.40 & 1.30 & 5.60 & 0.90 & 113.50 & 0.46 & 0.43 & 8.00 & 0.90 & 5.00 & 87.42 & 12.79 & 2.67 & 1.18 & 8.90 & 1.30 \\
\hline $\mathrm{Z}-1$ & $\begin{array}{l}\text { Bioturbated } \\
\text { limestone }\end{array}$ & 4.00 & 1.00 & 2.00 & 2.00 & 1.00 & 4.60 & 0.90 & 119.50 & 0.36 & 0.34 & 7.00 & 0.90 & 2.00 & 87.89 & 13.99 & 3.50 & 1.00 & 7.80 & 1.36 \\
\hline Z-13 & $\begin{array}{l}\text { Bioturbated } \\
\text { limestone }\end{array}$ & 10.00 & 1.10 & 3.00 & 2.30 & 1.00 & 3.70 & 0.80 & 146.50 & 0.32 & 0.35 & 6.00 & 0.70 & 2.00 & 92.59 & 9.99 & 2.00 & 0.91 & 7.50 & 1.58 \\
\hline$Z-14$ & $\begin{array}{l}\text { Bioturbated } \\
\text { limestone }\end{array}$ & 14.00 & 0.90 & 2.00 & 1.90 & 0.90 & 3.70 & 0.80 & 163.50 & 0.31 & 0.32 & 5.00 & 0.80 & 11.00 & 91.42 & 13.99 & 2.50 & 1.00 & 6.30 & 1.79 \\
\hline Z-15 & $\begin{array}{l}\text { Bioturbated } \\
\text { limestone }\end{array}$ & 14.70 & 1.00 & 2.00 & 2.00 & 1.00 & 3.80 & 0.90 & 191.00 & 0.31 & 0.35 & 6.00 & 0.80 & 9.00 & 96.35 & 14.69 & 3.00 & 1.00 & 6.70 & 1.98 \\
\hline Z-16 & $\begin{array}{l}\text { Bioturbated } \\
\text { limestone }\end{array}$ & 10.80 & 1.10 & 2.00 & 1.90 & 1.30 & 6.00 & 0.80 & 131.00 & 0.49 & 0.64 & 6.00 & 1.00 & 3.00 & 91.46 & 10.79 & 3.00 & 1.18 & 7.50 & 1.43 \\
\hline$Z-17$ & $\begin{array}{l}\text { Bioturbated } \\
\text { limestone }\end{array}$ & 9.20 & 1.10 & 2.00 & 2.30 & 1.50 & 5.60 & 0.90 & 125.00 & 0.49 & 0.59 & 7.00 & 1.00 & 3.00 & 91.46 & 9.19 & 3.50 & 1.36 & 7.80 & 1.37 \\
\hline Z-18 & $\begin{array}{l}\text { Bioturbated } \\
\text { limestone }\end{array}$ & 11.90 & 1.10 & 2.00 & 2.00 & 1.40 & 5.80 & 1.10 & 128.50 & 0.50 & 0.68 & 9.00 & 1.10 & 3.00 & 92.12 & 11.89 & 4.50 & 1.27 & 8.20 & 1.39 \\
\hline Z-19 & $\begin{array}{l}\text { Bioturbated } \\
\text { limestone }\end{array}$ & 9.70 & 1.40 & 3.00 & 2.80 & 1.90 & 4.30 & 1.10 & 131.50 & 0.45 & 0.65 & 11.00 & 1.10 & 18.00 & 108.10 & 9.69 & 3.67 & 1.36 & 10.00 & 1.22 \\
\hline$Z-20$ & $\begin{array}{l}\text { Bioturbated } \\
\text { limestone }\end{array}$ & 10.40 & 1.40 & 3.00 & 3.10 & 1.90 & 4.60 & 1.20 & 125.50 & 0.54 & 0.75 & 12.00 & 1.20 & 21.00 & 106.46 & 10.39 & 4.00 & 1.36 & 10.00 & 1.18 \\
\hline$Z-21$ & Dolostone & 5.20 & 1.10 & 2.00 & 2.20 & 1.30 & 1.90 & 0.90 & 62.40 & 0.35 & 0.41 & 6.00 & 0.90 & 6.00 & 70.97 & 5.19 & 3.00 & 1.18 & 6.70 & 0.88 \\
\hline Z-22 & Dolostone & 5.80 & 1.10 & 3.00 & 2.10 & 1.30 & 1.90 & 0.80 & 63.30 & 0.37 & 0.42 & 8.00 & 1.00 & 4.00 & 71.21 & 5.79 & 2.67 & 1.18 & 10.00 & 0.89 \\
\hline Average & - & 10.03 & 1.06 & 2.41 & 2.13 & 1.14 & 3.58 & 0.85 & 116.59 & 0.37 & 0.41 & 7.32 & 0.95 & 8.95 & 93.89 & 10.02 & 3.11 & 1.06 & 8.80 & 1.21 \\
\hline AUCC & - & 550 & 10 & 35 & 25 & 20 & 112 & 11 & 350 & 10.7 & 2.8 & 60 & 22 & 71 & - & - & - & - & - & - \\
\hline
\end{tabular}

$\mathbf{B a}_{\mathbf{e x}}=\mathrm{Ba}_{\text {total }}-\mathrm{Al}_{\text {total }} \times(\mathrm{Ba} / \mathrm{Al})_{\text {AucC }}($ Xiang et al. 2017)

\subsection{Relationship between bioturbation and oxygen concentration in sediments}

The enrichment of some trace elements, such as $U$ and $\mathrm{V}$, is controlled by redox conditions and slightly affected by terrigenous detritus. Therefore, the ratios of some trace elements can be used as an effective tool to determine redox conditions in the sedimentary period (Jones and Manning 1994; Kamber et al. 2001; ArmstrongAltrin et al. 2015; Ndjigui et al. 2018). Vanadium is present in multiple valence states in seawater under different redox conditions, such as, $\mathrm{V}^{5+}$ in vanadate oxyanions $\left(\mathrm{HVO}_{4}{ }^{2-}\right.$ or $\left.\mathrm{H}_{2} \mathrm{VO}_{4}{ }^{2-}\right), \mathrm{V}^{4+}$ in vanadyl ion $\left(\mathrm{VO}^{2-}\right)$, and $\mathrm{V}^{3+}$ in vanadium trioxide $\left(\mathrm{V}_{2} \mathrm{O}_{3}\right)$. Different vanadium ions are formed under the anoxic conditions present at the sediment-water interface, moderately reductive conditions, and strongly reductive conditions, respectively (Algeo and Maynard 2004; Tribovillard et al. 2006). Low $\mathrm{V} / \mathrm{Cr}$ ratios represent oxic environments, while high $\mathrm{V} / \mathrm{Cr}$ ratios indicate anoxic redox conditions (Kimura and Watanabe 2001; Table 4). In addition, the $\mathrm{V} / \mathrm{Sc}$ ratio is also a useful indicator for estimating redox conditions, with low $\mathrm{V} / \mathrm{Sc}$ ratios representing oxic 


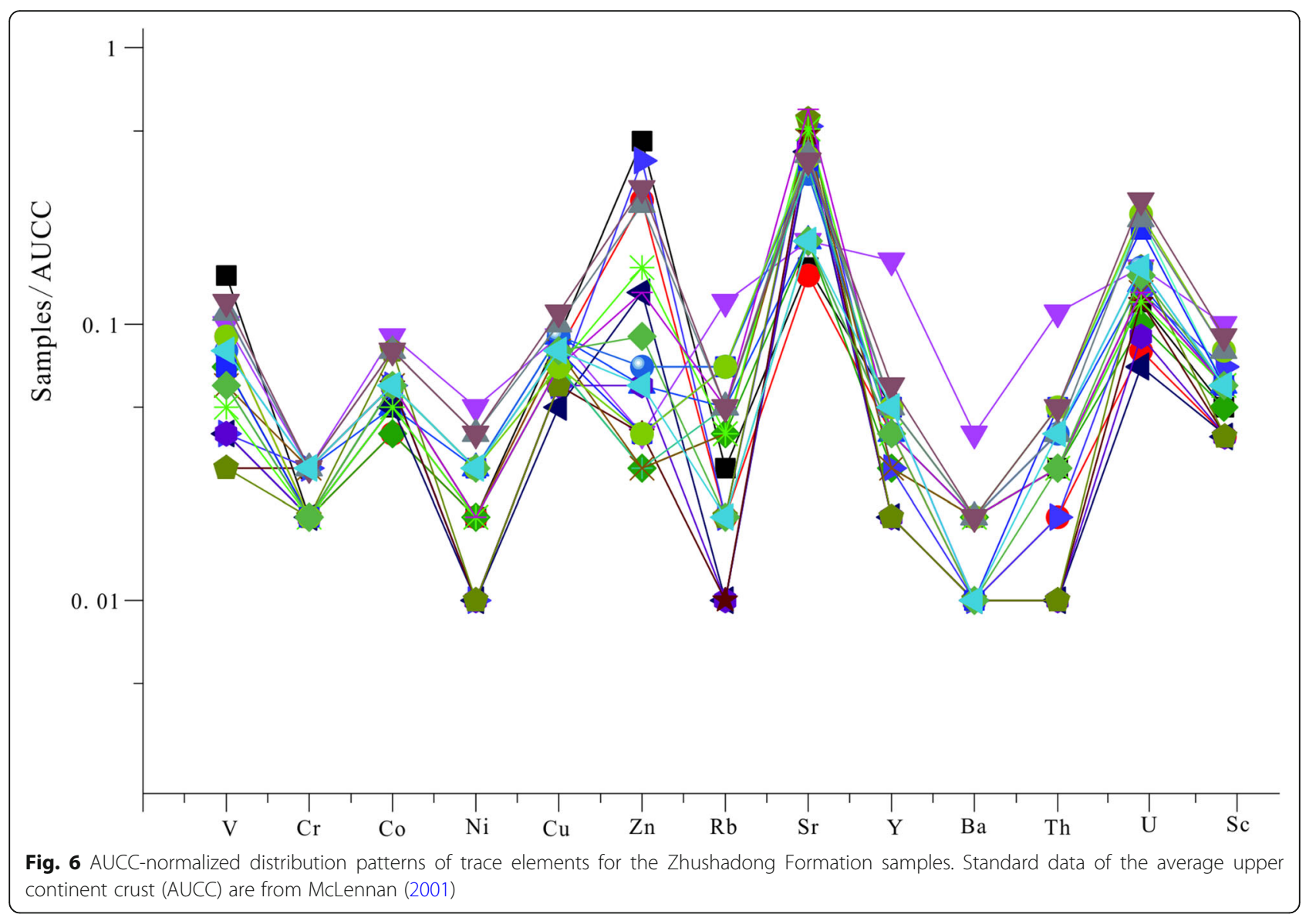

environments and high ratios representing anoxic environments (Murry et al. 1991; Table 4). The ratios of Ni/ Co have also been widely used as an indicator for palaeo-redox conditions, with $\mathrm{Ni} / \mathrm{Co}$ ratios of $<5$ reflecting oxic conditions, $\mathrm{Ni} / \mathrm{Co}$ ratios of $5-7$ representing dysoxic conditions and ratios of $>7$ representing suboxic to anoxic conditions (Jones and Manning 1994). The detailed criteria for categorizing redox conditions are presented in Table 4. The Zhushadong Formation contains areas of various redox conditions, from anoxic to oxic (Tables 3 and 4; Fig. 7). As shown in Fig. 7, there are three obvious stages in the Zhushadong Formation of the Guankou section, with the laminated dolostone

Table 4 The standard divisions based on trace element ratios for categorizing redox conditions

\begin{tabular}{lllll}
\hline Parameters & \multicolumn{1}{l}{ Anoxic } & \multicolumn{2}{l}{ Oxic } & Sources \\
\cline { 2 - 3 } & Anoxic & Suboxic & & \\
\hline Oxygen (ml/l) & $0-0.2$ & $0.2-2$ & $>2$ & Tyson and Pearson (1991) \\
$\mathrm{V} / \mathrm{Cr}$ & $>4.25$ & $2-4.25$ & $<2$ & Kimura and Watanabe (2001) \\
$\mathrm{Ni} / \mathrm{Co}$ & $>7$ & $5-7$ & $<5$ & Jones and Manning (1994) \\
$\mathrm{V} / \mathrm{SC}$ & $>9.1$ & & $<9.1$ & Murry et al. (1991) \\
\hline
\end{tabular}

having relatively low sediment oxygen concentrations while bioturbated limestone having higher sediment oxygen concentrations.

The lower Zhushadong Formation exhibits a negligible amount of bioturbation, with preservation of the primary fabric in rocks, characterized by algal and parallel laminations. Parallel lamination is related to the activities of microorganisms such as cyanobacteria, which bind sediment particles together to form organic sedimentary structures in the form of microbial mats and films due to organic mineralization and diagenesis (Krumbein 1983). Cyanobacteria are primarily present on the surface of microbial mats (Awramik and Sprinkle 1999). The absorption of $\mathrm{CO}_{2}$ and/or $\mathrm{HCO}^{3-}$ by cyanobacteria during photosynthesis increases the alkalinity of the surrounding environment and promotes the precipitation of carbonate. In the lower layers of the microbial mat, the environment is relatively closed, forming a suboxic and/or anoxic layer. Sulfate-reducing bacteria consume $\mathrm{SO}_{4}{ }^{2-}$ and organic carbon compounds, promoting the precipitation of carbonate. A study by Berner (2009) showed that the oxygen concentration in the atmosphere was $21 \%$ throughout the Phanerozoic and that cyanobacteria exposed to the air were rapidly oxidized and 


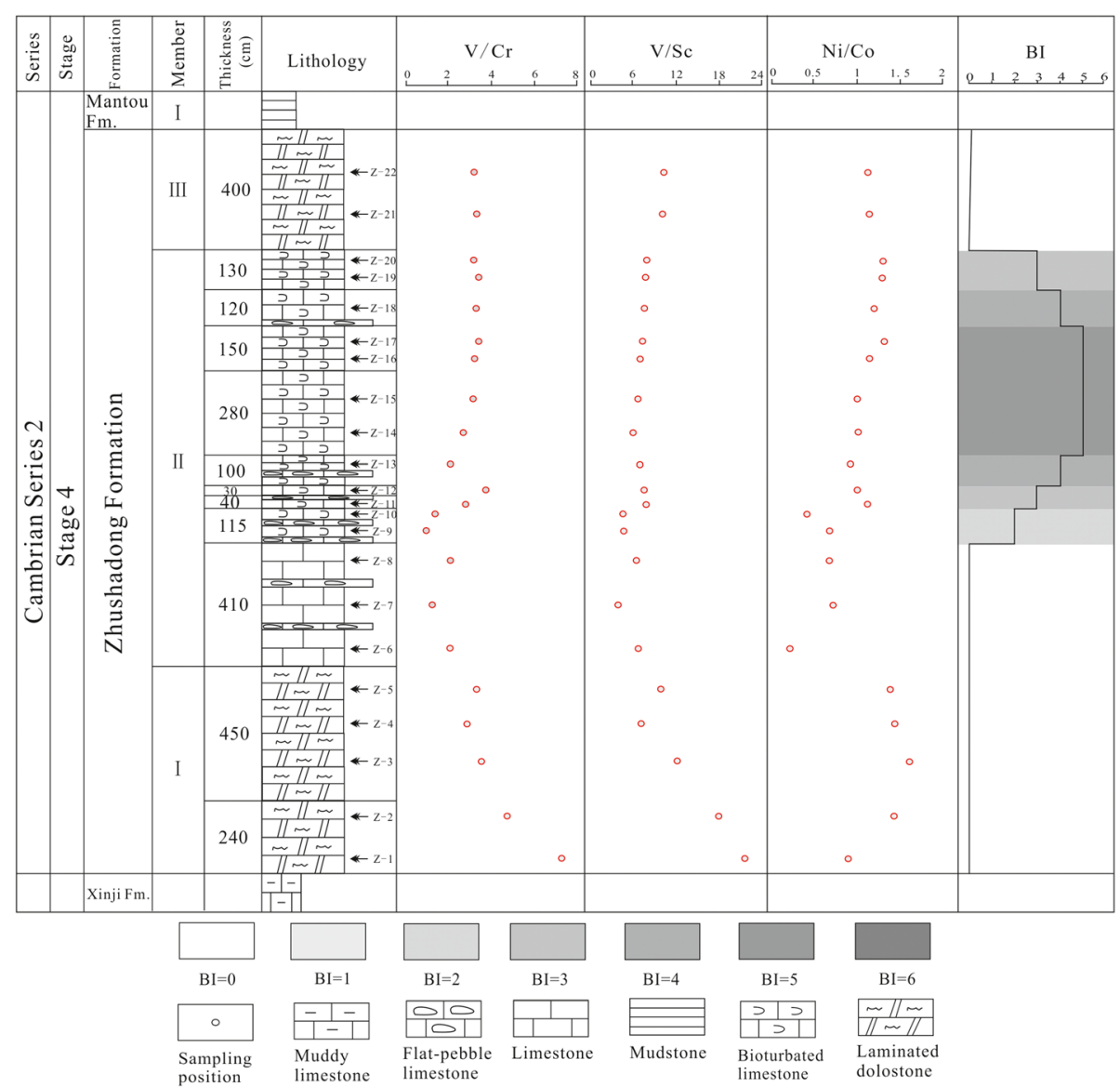

Fig. 7 Stratigraphic variation in redox proxies (V/Cr ratio, V/Sc ratio, Ni/Co ratio) of the Zhushadong Formation samples. $\mathrm{Bl}=\mathrm{Bioturbation}$ Index

degraded after death. Meanwhile, Riding et al. (2019) compared the abundance of microbial rocks in the Phanerozoic with historical data on dissolved oxygen concentrations in seawater, finding that oxygen-rich seawater is not conducive to the formation of microbial rocks because micro-organisms may have been oxidized and decomposed in the absence of calcification. Therefore, the oxygen concentration in sediment forming laminated dolomite should be relatively low.

Thalassinoides is present in shallow-marine carbonates of the Lower Cambrian Zhushadong Formation of North China (Qi et al. 2014; Zhang et al. 2017). They are burrows with vertical shafts and branches, exhibiting pathways for allowing water column to enter the subsurface. The reworking of sediments by bioturbators results in less compact sediments with increased porosities and redox active areas, and promoting oxygen flow within the sediments (Aller 1994). Thalassinoides from the Lower Cambrian exhibits very high ecosystem engineer impact (EEI) values (10-12) (Herringshaw et al. 2017), indicating that the producers have a strong ability to transport in downward or upward directions and the burrows are likely to be affected by biological irrigation, which is more conducive to transport oxygen to sediments (Herringshaw et al. 2017). Similar scenarios have been proposed in studies of modern bioturbation, showing that modern bioturbation can increase the transfer of oxygen from the water column into deeper sediment layers, with oxygen concentration being 1.5- to 4-fold higher than non-bioturbated sediments (Nicholaus et al. 2019). Thereby, bioturbation can significantly increase oxygen concentrations in sediments.

\subsection{Relationship between bioturbation and nutrient regeneration in sediments}

Burrowing of macrobenthos has a significant effect on the content and spatial distribution of organic matter, as well as on the concentration of nutrients in sediments (Meysman et al. 2006; Janas et al. 2019). The burrowing activity and feeding behavior of benthic organisms produce a large number of tunnels, which can increase sediment porosity by changing the particle size and distribution of sediment material (Lohrer et al. 2004; Nicholaus et al. 2019). Moreover, benthic biological activity can improve the pore water content of sediments by vertical mixing of particles and effectively promote 
material exchange at the sediment-water interface (Landrum et al. 2004; Ciutat et al. 2007). In comparison with non-bioturbated sediments, high density burrows affect organic carbon flux patterns and increase dissolved inorganic nitrogen flux (D'Andrea and DeWitt 2009).

Ocean productivity is mainly controlled by nutrient regeneration, and trace element records can be used to reflect palaeo-productivity (Dymond et al. 1992; Algeo and Maynard 2004; Schoepfer et al. 2015), which allows interpretation of seawater nutrient dynamics. The concentrations of $\mathrm{Ba}, \mathrm{Cu}, \mathrm{Ni}, \mathrm{P}, \mathrm{C}$, and $\mathrm{N}$ exhibit good relationships with marine productivity, due to their associations with organic carbon (Schoepfer et al. 2015). However, diagenesis and fluid circulation lead to changes in $\mathrm{P}, \mathrm{C}$, and $\mathrm{N}$ concentrations, resulting in less reliable relationships (Wei 2012). In particular, phosphorus preservation depends on the redox conditions and therefore, relatively low P concentrations may occur in sediments of high productivity areas (Fang et al. 2019). However, the geochemical properties of $\mathrm{Ba}$ are stable, often existing in the form of $\mathrm{BaSO}_{4}$ and exhibiting long preservation time, resulting in a strong correlation with nutrient concentrations and/or productivity in seawater (Jaccard et al. 2013; Fang et al. 2019).
However, using $\mathrm{Ba}$ to reflect the palaeo-productivity needs to eliminate the influence of terrestrial sources (Yan et al. 2018; Fang et al. 2019). The specific formula (Xiang et al. 2017) is: $\mathrm{Ba}_{\mathrm{ex}}=\mathrm{Ba}_{\text {total }}-\mathrm{Al}_{\text {total }} \times(\mathrm{Ba} / \mathrm{Al})_{\mathrm{AUCC}}$. In addition, several trace elements, such as $\mathrm{Cu}$ and $\mathrm{Ni}$, have been interpreted as possible indicators of planktonic primary productivity (Tribovillard et al. 2006; Piper and Calvert 2009). Moreover, there is a positive correlation between $\mathrm{Sr} / \mathrm{Ca}$ ratios and palaeontological assemblages indicating nutritional conditions, which can also be used to indicate changes in productivity (Stoll and Schrag 2001).

Stratigraphically, the trends in concentrations of $\mathrm{Ba}_{\mathrm{ex}}$, $\mathrm{Cu}$, and $\mathrm{Ni}$, as well as $\mathrm{Sr} / \mathrm{Ca}$ ratios follow a three-step pattern consistent with the BI variation (Fig. 8), with values being low in Member I, then increasing substantially in Member II, and decreasing again in Member III (Tables 1 and 3; Fig. 8). Sediments bioturbated by Thalassinoides exhibit altered patterns of nutrient regeneration. The complex burrow system of Thalassinoides changes the particle size and structure, increases the water conversion area, and improves the living environment for microorganisms, with enhanced adsorption in sediments and promotion of nitrogen-fixing microorganism growths. In addition, bioturbation also increases the

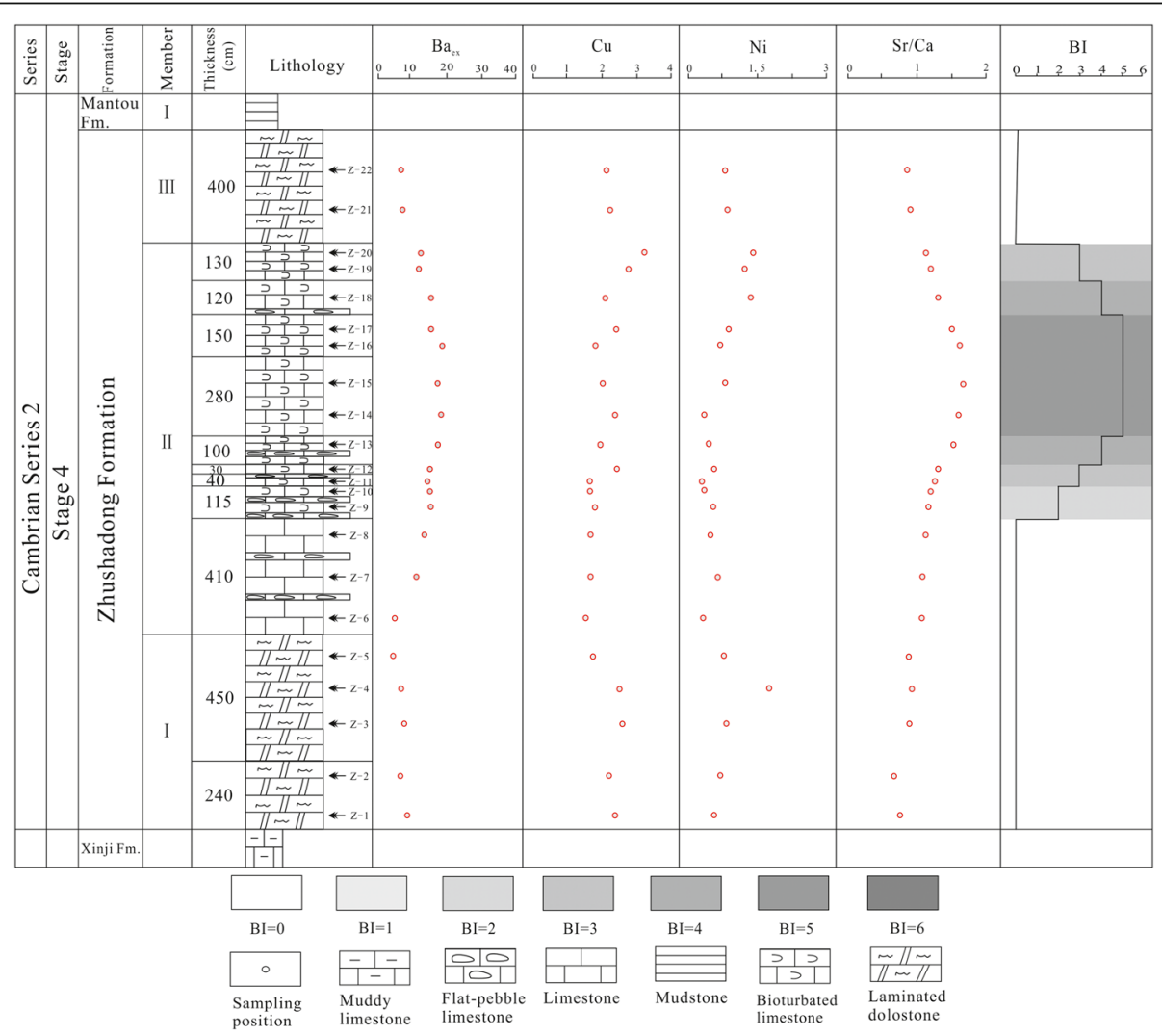

Fig. 8 Stratigraphic variation in concentrations of $\mathrm{Ba}_{\mathrm{ex}}, \mathrm{Cu}, \mathrm{Ni}$, and $\mathrm{Sr} / \mathrm{Ca}$ ratios of the Zhushadong Formation samples. $\mathrm{Ba}_{\mathrm{ex}}=\mathrm{Ba}_{\text {total }}-\mathrm{Al}_{\text {total }} \times(\mathrm{Ba} /$

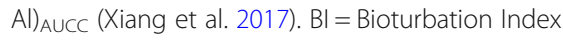


oxygen concentration, bacteria count and biological activity. The construction process of Thalassinoides can promote the transfer of organic matter (i.e. nitrogen and phosphorus) from the water column into the sediment and from shallow to deep sediments, enhancing organic matter concentrations. With the passage of time, the feeding, burrowing and excretion of Thalassinoides bioturbators promote the decomposition of organic matter and its circulation back into the water column, and then increase concentrations of the ammonia nitrogen, total nitrogen and total phosphorus in the water column (Ziebis et al. 1996).

\subsection{Influence of burrowing activities on sediments}

As described in section 4 (Results), the Thalassinoides burrow system in the Guankou section is composed of unlined shafts and complex branchings. The presence of shafts indicates that the Thalassinoides of the Zhushadong Formation in the Guankou section differed from those of the Upper Cambrian-Lower Ordovician in Colorado (USA) (Myrow 1995). The presence of shafts in the Zhushadong Formation shows that Thalassinoides burrowed into sediments from the sediment-water interface, promoting material exchanges between seawater and sediments, and enhancing the permeability of sediments (Lohrer et al. 2004). Moreover, Thalassinoides producers propelled the water cycling to improve the oxygen concentration in burrow system, creating a favorable place for bacteria capable of ammonia oxidation. Thalassinoides bioturbation can increase microbial reproduction rates and microbial activities (Pillay et al. 2011). Previous studies (Bromley 1996; Wang et al. 2019) have considered that Thalassinoides in some cases might be an agrichnial burrow system, in which the tracemaker was fed on microbial cultures growing on/in the burrow walls. The microbial prosperity provides a rich food source for the Thalassinoides producer, moreover, it promotes biological metabolism of compounds such as ammonium, nitrate, nitrite, organic matter and other carbon compounds, with ions and/or solutes effectively being transferred to the water column (Aller 1994; Ziebis et al. 1996; Stamhuis et al. 1997; D'Andrea and DeWitt 2009; Repetto and Griffen 2012; Nicholaus et al. 2019), significantly affecting the biogeochemical cycle at the sediment-water interface. Interestingly, a modern study found that microorganisms, combined with bioturbation, are directly and/or indirectly involved in the release of benthic nutrients (Shen et al. 2017).

In order to better understand the influence of Thalassinoides burrows in sediments of the Zhushadong Formation, it is necessary to compare them with modern similar burrows. There are numerous modern examples of thalassinid shrimps found in burrows with the characteristics of Thalassinoides (Glaessner 1957; Beikirch and
Feldmann 1980). During the Paleozoic, arthropods, sea anemones and worm-like bioturbators are probable candidates for producers of Thalassinoides (Ekdale and Bromley 2003; Cherns et al. 2006; Ding et al. 2020). No matter in which geological period, the Paleozoic to modern time, all of Thalassinoides have same characteristics and have a three-dimensional boxwork of branched cylindrical burrow system sometimes interconnected by vertical shafts. The burrow system and living environment of Callianassa subterranea, a modern burrowing organism, are similar to those of the Thalassinoides producer in the Zhushadong Formation; and Callianassa subterranea also feeds on organic matter and microorganisms in sediments (Stamhuis et al. 1997; Fan et al. 2020). In the process of sediment restructuring, the Thalassinoides producer needs sufficient oxygen to maintain life activities and transport treated fine sediment particles to the surface. This behavioral strategy requires at least one suction inlet and one discharge outlet (Stamhuis et al. 1997). They effectively release fluids outward when releasing excrements through the outlet, and with the introduction of compensatory fluid at the suction inlet, they can enhance seawater transfer to the burrow system. In this way, dissolved oxygen and nutrients in seawater can be effectively transported to the burrow, increasing their content in burrows and sediments (Ziebis et al. 1996; Pillay and Branch 2011). Bioturbation leads to increases of organic carbon, nitrogen concentration and microbial abundance also in other Thalassinoides burrows (Kinoshita et al. 2008), further verifying that bioturbation can promote oxygen concentration and nutrient regeneration in sediments.

In addition, during sediment transformation, Thalassinoides producers destroy primary sedimentary structures, resulting in mixing of sediments and making them softer (Fig. 9a), and leading to increased sediment permeability. The permeability increase is conducive to the transfer of dissolved oxygen from seawater to the pore water (Brlek et al. 2014; El-Sabbagh et al. 2017). When sedimentation rate decreased, organisms can re-burrow the underlying burrowed sediment, which further enhances sediment mixing (Fig. 9b). With increasing sedimentation rate, burrowing is inhibited and sediment mixing caused by bioturbation is restricted to within the sediments. With the reduction of sedimentation, Thalassinoides producers begin burrowing again, forming the next bioturbation layer (Fig. 9c). Because of the highly suitable environment, the Thalassinoides producers can repeatedly bioturbate the sediment and entirely destroy original sedimentary structures, and then change original physico-chemical characteristics. Oxygen concentration and nutrient regeneration in the bioturbated mix ground are significantly higher and more active than in nonbioturbated layers (Shen et al. 2017). Thalassinoides 


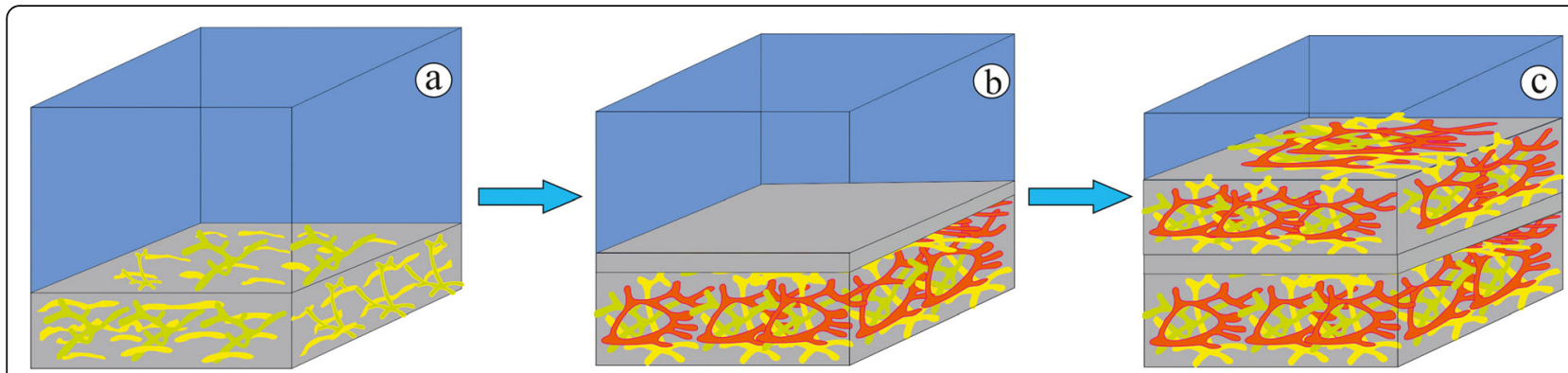

Fig. 9 The reworking process of Thalassinoides producers from the Zhushadong Formation in the Guankou section (modified from Qi et al. 2014). a Thalassinoides producers were burrowing in sediments; $\mathbf{b}$ When the sedimentation rate increased, Thalassinoides producers were forced to stop burrowing; $\mathbf{c}$ With decrease of the sedimentation rate, Thalassinoides producers began burrowing again, forming next bioturbation layer

enables their producers to better filter organic matter from seawater and sediments, while such burrow system has higher oxygen concentrations and greater potentials for biological irrigation (Herringshaw et al. 2017). As proposed by Darwin (1881), animal-bioturbated sediments provide a broader living space for microorganisms and promote their proliferation (Zhang et al. 2017). Therefore, Thalassinoides, serves as an ecosystem engineer in the Zhushadong Formation in the Guankou section, not only changing the original physical and chemical characteristics of the sediment, but also significantly increasing the oxygen concentration and nutrient content in the sediment.

\section{Conclusions}

Abundant bioturbation structures, dominated by Thalassinoides, occurred in carbonate sediments of the Cambrian Series 2 Zhushadong Formation in the Guankou section of Dengfeng area, Henan Province, North China. Thalassinoides was commonly composed of vertical unlined shafts and horizontal tunnels, with branches and burrow expansion mostly occurring via junctions. Reworking of sediments by the burrowing organisms was rapid, and the bioturbation index ranged between 2 and 5 .

Based on geochemical analyses, oxygen of the Zhushadong Formation evolved from low concentrations in the lower laminated dolostone of Member I, to high concentrations in the bioturbated limestone of Member II, and diminished again in the upper laminated dolostone of Member III. Nutrient regeneration and oxygen concentration exhibited the similar trend. Moreover, changes in nutrient regeneration and oxygen concentrations were directly proportional to the intensity of bioturbation.

Compared with recently assessed modern producers of Thalassinoides, the burrowing activities of the Thalassinoides producers in the Zhushadong Formation functioned as early ecosystem engineers. The sediment disturbance by the producers significantly affected the biogeochemical cycling, especially in terms of the migration of oxygen and nutrients in sediments.

\section{Acknowledgements}

The authors sincerely thank the Editor-in-Chief Prof. Zeng-Zhao Feng, the Associate Editor-in-Chief Prof. Stephen Kershaw, and anonymous reviewers for their constructive recommendations for this manuscript.

\section{Authors' contributions}

YCF completed slice analysis, major and trace element analysis and data interpretation, and composed the original manuscript; YAQ directed the field work as well as the data analysis and interpretation; MYD, DL, BCL, and GSQ participated in the field work. All authors read and approved the final paper.

\section{Funding}

Financial support for this study was provided by the Natural Science Foundation of China (Grant Nos. 41872111, 41902115, and 41902113).

\section{Availability of data and materials}

All data and materials generated or analyzed during this study are included in this published paper.

\section{Competing interests}

The authors declare that they have no competing interests.

Received: 3 March 2020 Accepted: 2 December 2020

Published online: 07 January 2021

\section{References}

Algeo, T.J., and J.B. Maynard. 2004. Trace-element behavior and redox facies in core shales of upper Pennsylvanian Kansas-type cyclothems. Chemical Geology 206: 289-318.

Aller, R.C. 1994. Bioturbation and remineralization of sedimentary organic matter: Effects of redox oscillation. Chemical Geology 114: 331-345.

Armstrong-Altrin, J.S., M.L. Machain-Castillo, L. Rosales-Hoz, A. CarranzaEdwards, J.A. Sanchez-Cabeza, and A.C. Ruíz-Fernandez. 2015. Provenance and depositional history of continental slope sediments in the southwestern Gulf of Mexico unraveled by geochemical analysis. Continental Shelf Research 95: 15-26.

Awramik, S.M., and J. Sprinkle. 1999. Proterozoic stromatolites: The first marine evolutionary biota. Historical Biology 13 (4): 241-253.

Beikirch, D.W., and R.M. Feldmann. 1980. Decapods crustaceans from the Pflugerville member, Austin formation (late cretaceous: Campanian) of Texas. Journal of Paleontology 54: 309-324.

Berner, R.A. 2009. Phanerozoic atmospheric oxygen: New results using the GEOCARBSULF model. American Journal of Science 309 (7): 603-606.

Boyle, R.A., T.W. Dahl, C.J. Bjerrum, and D.E. Canfield. 2018. Bioturbation and directionality in Earth's carbon isotope record across the Neoproterozoic-Cambrian transition. Geobiology 16 (3): 252-278.

Boyle, R.A., T.W. Dahl, A.W. Dale, G.A. Shield-Zhou, M. Zhu, M.D. Brasier, D.E. Canfield, and T.M. Lenton. 2014. Stabilization of the coupled oxygen and phosphorus cycles by the evolution of bioturbation. Nature Geoscience 7 (9): 671-676. 
Brlek, M., T. Korbar, A. Košir, B. Glumac, A. Grizelj, and B. Otoničar. 2014. Discontinuity surfaces in upper cretaceous to Paleogene carbonates of central Dalmatia (Croatia): Glossifungites ichnofacies, biogenic calcretes, and stratigraphic implications. Facies 60 (2): 467-487.

Bromley, R.G. 1996. Trace fossils: biology and taphonomy, 280. London: Chapman \& Hall.

Buatois, L.A., G.M. Narbonne, M.G. Mángano, N.B. Carmona, and P. Myrow. 2014. Ediacaran matground ecology persisted into the earliest Cambrian. Nature Communications 5: 35-44.

Canfield, D.E., and J. Farquhar. 2009. Animal evolution, bioturbation, and the sulfate concentration of the oceans. Proceedings of the National Academy of Sciences of the United States of America 106 (20): 8123-8127.

Carvalho, C.N.D., P.A. Viegas, and MárioCachão. 2007. Thalassinoides and its producer: Populations of Mecochirus buried within their burrow systems, Boca do Chapim formation (lower cretaceous), Portugal. Palaios 22 (1): 104-109.

Chen, Z., C.M. Zhou, M. Meyer, X. Xiang, J.D. Schiffbauer, X.L. Yuan, and S.H. Xiao. 2013. Trace fossil evidence for Ediacaran bilaterian animals with complex behaviors. Precambrian Research 224: 690-701.

Cherns, L., J.R. Wheelye, and L. Karis. 2006. Tunneling trilobites: Habitual infaunalism in an Ordovician carbonate seafloor. Geology 34: 657-660.

Ciutat, A., M. Gerino, and A. Boudou. 2007. Remobilization and bioavailability of cadmium from historically contaminated sediments: Influence of bioturbation by tubificids. Ecotoxicology and Environmental Safety 68 (1): 108-117.

D'Andrea, A.F., and T.H. DeWitt. 2009. Geochemical ecosystem engineering by the mud shrimp Upogebia pugettensis (Crustacea: Thalassinidae) in Yaquina Bay, Oregon: Density-dependent effects on organic matter remineralization and nutrient cycling. Limnology and Oceanography 54 (6): 1911-1932.

Darwin, C. 1881. The formation of vegetable mould through the action of worms, with observations on their habits, 326. London: John Murray.

Ding, Y., J.N. Liu, F.F. Chen, and X.D. Wang. 2020. Ichnology, palaeoenvironment, and ecosystem dynamics of the early Cambrian (stage 4, series 2) Guanshan Biota, South China. Geological Journal 55 (1): 77-94.

Dornbos, S.Q., D.J. Bottjer, and J.Y. Chen. 2005. Paleoecology of benthic metazoans in the early Cambrian Maotianshan shale biota and the middle Cambrian burgess shale biota: Evidence for the Cambrian substrate revolution. Palaeogeography, Palaeoclimatology, Palaeoecology 220 (1-2): 47-67.

Dymond, J., E. Suess, and M. Lyle. 1992. Barium in deep-sea sediment: A geochemical proxy for paleoproductivity. Paleoceanography 7 (2): 163-181.

Ekdale, A.A., and R.G. Bromley. 2003. Paleoethologic interpretation of complex Thalassinoides in shallow-marine limestones, lower Ordovician, southern Sweden. Palaeogeography, Palaeoclimatology Palaeoecology 192: 221-227.

El-Sabbagh, A., M. El-Hedeny, and S.A. Farraj. 2017. Thalassinoides in the middle Miocene succession at Siwa Oasis, northwestern Egypt. Proceedings of the Geologists' Association 128 (2): 222-233.

Fan, Y.C., Y.A. Qi, M.Y. Dai, G.S. Qing, B.C. Liu, and W.B. Bai. 2020. Paleoclimate evolution recorded in the Cambrian Epoch 2 Zhushadong Formation from Dengfeng area, western Henan Province. Journal of Palaeogeography (Chinese Edition) 22 (2): 367-376.

Fang, X.Y., L.L. Wu, A.S. Geng, and Q. Deng. 2019. Formation and evolution of the Ediacaran to Lower Cambrian black shales in the Yangtze platform, South China. Palaeogeography, Palaeoclimatology, Palaeoecology 527: 87-102.

Glaessner, M.F. 1957. Palaeozoic arthropod trail from Australia. Paläontologische Zeitschrift 3: 103-109.

Herringshaw, L.G., R.H.T. Callow, and D. Mcilroy. 2017. Engineering the Cambrian explosion: The earliest bioturbators as ecosystem engineers. Geological Society of London, Special Publications 448: 369-382.

Jaccard, S.L., C.T. Hayes, A. Martínez-García, D.A. Hodell, R.F. Anderson, D.M. Sigman, and G.H. Haug. 2013. Two modes of change in southern ocean productivity over the past million years. Science 339 (6126): 1419-1423.
Janas, U., D. Burska, H. Kendzierska, D. Pryputniewicz-Flis, and K. LukawskaMatuszewska. 2019. Importance of benthic macrofauna and coastal biotopes for ecosystem functioning - Oxygen and nutrient fluxes in the coastal zone. Estuarine Coastal and Shelf Science 225: 106-238.

Jones, B., and D.A.C. Manning. 1994. Comparison of geochemical indices used for the interpretation of palaeoredox conditions in ancient mudstones. Chemical Geology 111: 111-129.

Kamber, B.S., S. Moorbath, and M.J. Whitehouse. 2001. The oldest rocks on earth: Time constraints and geological controversies. Geological Society of London, Special Publications 190: 177-203.

Kimura, H., and Y. Watanabe. 2001. Oceanic anoxia at the PrecambrianCambrian boundary. Geology 29 (11): 995-998

Kinoshita, K., M. Wada, K. Kogure, and T. Furota. 2008. Microbial activity and accumulation of organic matter in the burrow of the mud shrimp, Upogebia major, (Crustacea: Thalassinidea). Marine Biology 153 (3): 277-283.

Krumbein, W.E. 1983. Stromatolites - The challenge of a term in space and time. Precambrian Research 20 (2-4): 493-531.

Landrum, P.F., M. Leppänen, S.D. Robinson, D.C. Gossiaux, and M.B. Lansing.

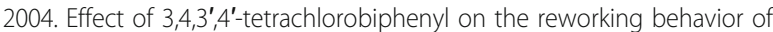
Lumbriculus variegatus exposed to contaminated sediment. Environmental Toxicology and Chemistry 23 (1): 178-186.

Liu, Y.J., L.M. Cao, Z.L. Li, H.N. Wang, and T.Q. Chu. 1984. Elemental geochemistry, 360-372. Beijing: Science Press (in Chinese with English Abstract).

Lohrer, A.M., S.F. Thrush, and M.M. Gibbs. 2004. Bioturbators enhance ecosystem function through complex biogeochemical interactions. Nature 431 (7012): 1092-1095.

Mángano, M.G., and L.A. Buatois. 2004. Reconstructing early Phanerozoic intertidal ecosystems: Ichnology of the Cambrian Campanario formation in Northwest Argentina. Fossils and Strata 51 (51): 17-38.

Mángano, M.G., and L.A. Buatois. 2014. Decoupling of body-plan diversification and ecological structuring during the EdiacaranCambrian transition: Evolutionary and geobiological feedbacks Proceedings of the Royal Society B: Biological Sciences 281 (1780): 20140038. https://doi.org/10.1098/rspb.2014.0038.

McLennan, S.M. 2001. Relationships between the trace element composition of sedimentary rocks and upper continental crust. Geochemistry Geophysics Geosystems 2 (4). https://doi.org/10.1029/2000GC000109.

Meysman, F.J., J.J. Middelburg, and C.H. Heip. 2006. Bioturbation: A fresh look at Darwin's last idea. Trends in Ecology \& Evolution 21 (12): 688-695.

Michaud, E., G. Desrosiers, F. Mermillod-Blondin, B. Sundby, and G. Stora. 2005. The functional group approach to bioturbation: The effects of biodiffusers and gallery-diffusers of the Macoma balthica community on sediment oxygen uptake. Journal of Experimental Marine Biology and Ecology 326 (1): 77-88.

Michaud, E., G. Desrosiers, F. Mermillod-Blondin, B. Sundby, and G. Stora. 2006. The functional group approach to bioturbation: li. The effects of the Macoma balthica community on fluxes of nutrients and dissolved organic carbon across the sediment-water interface. Journal of Experimental Marine Biology and Ecology 337 (2-3): 178-189.

Murry, R.W., M.R. Buchholtz, D.C. Gerlach, and G. Price Russ III. 1991. Rare earth, major, and trace elements in chert from the Franciscan complex and Monterey group, Californian: Assessing REE sources to fine-grained marine sediments. Geochimica et Cosmochimica Acta 55 (7): 1875-1895.

Myrow, P.M. 1995. Thalassinoides and the enigma of early Paleozoic open framework burrow systems. Palaios 10 (1): 58-74.

Ndjigui, P.D., V.L. Onana, E. Sababa, and E.C. Bayiga. 2018. Mineralogy and geochemistry of the Lokoundje alluvial clays from the Kribi deposits, Cameroonian Atlantic coast: Implications for their origin and depositional environment. Journal of African Earth Sciences 143: 102-117.

Nicholaus, R., B. Lukwambe, L. Zhao, W. Yang, J.Y. Zhu, and Z.M. Zheng. 2019. Bioturbation of blood clam Tegillarca granosa on benthic nutrient fluxes and microbial community in an aquaculture wastewater treatment system. International Biodeterioration \& Biodegradation 142: $73-82$. 
Nickell, L.A., and R.J.A. Atkinson. 1995. Functional morphology of burrows and trophic modes of three thalassinidean shrimp species, and a new approach to the classification of thalassinidean burrow morphology. Marine Ecology Progress Series 128 (1): 181-197.

Pei, F., H.Q. Zhang, G.S. Yan, and Y.B. Xi. 2008. Research on stratigraphic paleontology in Henan Province, volume 3, early Paleozoic (North China). Zhengzhou: Yellow River Water Conservancy Press (in Chinese with English Abstract).

Pillay, D., and G.M. Branch. 2011. Bioengineering effects of burrowing thalassinidean shrimps on marine soft-bottom ecosystems. Oceanography and Marine Biology 49: 137-192.

Pillay, D., G.M. Branch, J. Dawson, and D. Henry. 2011. Contrasting effects of ecosystem engineering by the cordgrass Spartina maritima and the sandprawn Callianassa kraussi in a marine-dominated lagoon. Estuarine Coastal and Shelf Science 91 (2): 169-176.

Piper, D.Z., and S.E. Calvert. 2009. A marine biogeochemical perspective on black shale deposition. Earth-Science Reviews 95 (1): 63-96.

Qi, Y.A. 1999. The description and analysis of bioturbation and ichnofabric Henan Geology 17 (4): 273-277 (in Chinese with English Abstract).

Qi, Y.A., Y. Meng, M.Y. Dai, and D. Li. 2014. Biogenic leopard patch structures from the Zhushadong Formation (Cambrian series 2), Dengfeng area, Western Henan. Geological Science and Technology Information 33 (5): 18 (in Chinese with English Abstract)

Repetto, M., and B.D. Griffen. 2012. Physiological consequences of parasite infection in the burrowing mud shrimp, Upogebia pugettensis, a widespread ecosystem engineer. Marine and Freshwater Research 63 (1): $60-67$.

Riding, R., L. Liang, J.H. Lee, and A. Virgone. 2019. Influence of dissolved oxygen on secular patterns of marine microbial carbonate abundance during the past 490 Myr. Palaeogeography, Palaeoclimatology, Palaeoecology 514: 135-143.

Schoepfer, S.D., J. Shen, H.Y. Wei, R.V. Tyson, E. Ingall, and T.J. Algeo. 2015. Total organic carbon, organic phosphorus, and biogenic barium fluxes as proxies for paleomarine productivity. Earth-Science Reviews 149: 23-52.

Seilacher, A. 1999. Biomat-ralated lifestyles in the Precambrian. Palaios 14 (1): 86-93.

Shen, H., G. Jiang, X.H. Wan, H. Li, Y. Qiao, S. Thrush, and P.H. He. 2017. Response of the microbial community to bioturbation by benthic macrofauna on intertidal flats. Journal of Experimental Marine Biology and Ecology 488: 44-51.

Stamhuis, E.J., C.E. Schreurs, and J.J. Videler. 1997. Burrow architecture and turbative activity of the thalassinid shrimp Callianassa subterranea from the Central North Sea. Marine Ecology Progress Series 151 (1-3): 155-163.

Stoll, H.M., and D.P. Schrag. 2001. Sr/Ca variations in cretaceous carbonates: Relation to productivity and sea level changes. Palaeogeography, Palaeoclimatology, Palaeoecology 168 (3-4): 311-336.

Tarhan, L.G. 2018. The early Paleozoic development of bioturbation Evolutionary and geobiological consequences. Earth-Science Reviews 178: 177-207.

Taylor, A.M., and R. Goldring. 1993. Description and analysis of bioturbation and ichnofabric. Journal of Geological Society 150 (1): 141-148.

Tribovillard, N., T.J. Algeo, T. Lyons, and A. Riboulleau. 2006. Trace metals as paleoredox and paleoproductivity proxies: An update. Chemical Geology $232(1-2): 12-32$.

Tyson, R.V., and T.H. Pearson. 1991. Modern and ancient continental shelf anoxia: An overview. Arctic and Alpine Research 58 (1): 1-24.

Wang, M., K.N. Li, W.T. Yang, M.Y. Dai, W.B. Bai, and Y.A. Qi. 2019. The trace fossil Thalassinoides bacae in the Cambrian Zhangxia formation (Miaolingian series) of North China. Palaeogeography, Palaeoclimatology, Palaeoecology 534: 109333. https://doi.org/10.1016/j.palaeo.2019.109333.

Wei, H.Y. 2012. Productivity and redox proxies of palaeo-oceans: An overview of elementary geochemistry. Sedimentary Geology and Tethyan Geology 32 (2): 78-90 (in Chinese with English Abstract).

Xiang, L., S.D. Schoepfer, H. Zhang, X.L. Yuan, C.Q. Cao, Q.F. Zheng, C.M. Henderson, and S.Z. Shen. 2017. Oceanic redox evolution across the end-Permian mass extinction at Shangsi, South China. Palaeogeography, Palaeoclimatology, Palaeoecology 448: 59-71.
Yan, C.N., Z.J. Jin, J.H. Zhao, W. Du, and Q.Y. Liu. 2018. Influence of sedimentary environment on organic matter enrichment in shale: A case study of the Wufeng and Longmaxi formation of the Sichuan Basin, China. Marine and Petroleum Geology 92: 880-894.

Yang, Z.Y., Otofuji Yo-ichiro, Z.M. Sun, and B.C. Huang. 2002 Magnetostratigraphic constraints on the Gondwanan origin of North China: Cambrian/Ordovician boundary results. Geophysical Journal International 151 (1): 1-10.

Zhang, L.J., Y.A. Qi, L.A. Buatois, M.G. Mángano, Y. Meng, and D. Li. 2017. The impact of deep-tier burrow systems in sediment mixing and ecosystem engineering in early Cambrian carbonate settings. Scientific Reports 7: 45773. https://doi.org/10.1038/srep45773.

Zhang, W., X. Shi, G. Jiang, D. Tang, and X. Wang. 2015. Mass-occurrence of oncoids at the Cambrian series 2-series 3 transition: Implications for microbial resurgence following an early Cambrian extinction. Gondwana Research 28 (1): 432-450.

Ziebis, W., S. Forster, M. Huettel, and B.B. Jørgensen. 1996. Complex burrows of the mud shrimp Callianassa truncata and their geochemical impact in the sea bed. Nature 382 (6592): 619-622.

\section{Publisher's Note}

Springer Nature remains neutral with regard to jurisdictional claims in published maps and institutional affiliations.

\section{Submit your manuscript to a SpringerOpen ${ }^{\circ}$ journal and benefit from:}

- Convenient online submission

- Rigorous peer review

- Open access: articles freely available online

- High visibility within the field

- Retaining the copyright to your article

Submit your next manuscript at $>$ springeropen.com 